\title{
Produced water reuse for irrigation of non-food biofuel crops: effects on switchgrass and rapeseed germination, physiology and biomass yield
}

\author{
Nasim E. Pica ${ }^{1}$, Ken Carlson ${ }^{1}$, Jeffrey J. Steiner ${ }^{2}$, Reagan Waskom ${ }^{3}$
}

\begin{abstract}
High volumes of flowback and produced water are generated everyday as a byproduct of hydraulic fracturing operations and shale gas developments across the United States. Since most shale gas developments are located in semi-arid to arid U.S. regions close to agricultural production, there are many opportunities for reusing these waters as potential alternatives or supplements to fresh water resources for irrigation activities. However, the impacts of high salinity and total organic content of these types of water on crop physiological parameters and plant growth needs to be investigated to determine their utility and feasibility. The aim of the present study was to evaluate the response of switchgrass and rapeseed to treated produced water as an irrigation water source. In this greenhouse study, the influence of produced water at four total organic carbon (TOC) concentrations $[1.22,38.3,232.2$ and $1352.4 \mathrm{mg} / \mathrm{l}]$ and three total dissolved solids (TDS) levels [400, 3,500, and 21,000 mg/l] on rapeseed (Brassica napus L.) and switchgrass (Panicum virgatum L.), two relatively salt-tolerant, non-food, biofuel crops, was
\end{abstract}


23 studied. Seedling emergence, biomass yield, plant height, leaf electrolyte leakage, and plant

24 uptake were evaluated. Irrigation water with the highest salinity and TOC concentration resulted

25 in significantly lower growth health and physiological characteristics of both crop species. The

26 organic content of the produced water had a negative impact on biomass yield and physiological

27 parameters of both species. The results of this study could be valuable for regulators and

28 stakeholders in development of treatment standards in which organic matter should be removed

29 to less than 50mg/l to keep leaf EL (cell damage) to less than 50\% and a TOC concentration of

30 less than $5 \mathrm{mg} / \mathrm{l}$ required to keep a sustainable biomass production rate.

31 Keywords: hydraulic fracturing, produced water, reuse, switchgrass, rapeseed, biofuel

\section{1. Introduction}

33 Large volumes of the injected water during hydraulic fracturing flows back to the surface with

34 the extracted oil and gas (Esmaeilirad et al., 2015). This water is called flowback at the early

35 well-life stage and produced water later during the life of a well. Approximately $90 \%$ of these

36 kinds of water are injected back into the ground in class II wells that are regulated by EPA's

37 Underground Injection Control program (Esmaeilirad et al., 2015; Boysen et al., 2011).

38 However, this method has been linked to induced seismic activity and frequent earthquakes in

39 Oklahoma and Texas, states that contain a large number of injection wells (Frohlich, 2012;

40 Nichloson and Wesson, 1990; Ellsworth, 2013; Keranen et al., 2013). Moreover, drought

41 conditions and competition for freshwater consumption, as well as environmental issues such as

42 chemical spills, $\mathrm{CO}_{2}$ and other greenhouse gas emissions, can result from trucking, the main

43 water transport method for oil and gas operations (Boschee, 2012). Considering the large volume

44 of produced water generated every day across the nation and the projected growth rate of water- 
45 intensive biofuel production (International Energy Agency, World energy outlook, 2012), using

46 produced water for irrigation may provide a potential alternative to the use of only freshwater

47 resources. High salinity, the total organic matter load, and the presence of toxic organic

48 compounds (e.g., benzene) are the main pollutant constituents in produced water that need to be

49 addressed when considering reuse for irrigation purposes.

50 In this study, we evaluated the impacts of produced water for irrigation on two non-food biofuel

51 crops, switchgrass and rapeseed. These species can tolerate a broad range of temperature, soil

$52 \mathrm{pH}$, and water salinity conditions, and can grow under salt-stressed, marginal soil conditions

53 (Alexopoulou et al., 2008; Lee et al., 2007; Lynd et al.,1991; McLaughlin et al., 2002;

54 McLaughlin et al., 2005; Sanderson et al., 1996). The salinity of the soil can cause osmotic and

55 specific ion effects (ionic stress) on plant cells that lead to nutrient imbalances affecting

56 important physiological and biochemical processes. These can ultimately inhibit plant growth

57 and development and reduce biomass production (Munns, 2005).

58 Switchgrass, a native North American, warm-season (C4 metabolism), perennial grass, is rich in

59 natural diversity and adapted to grow over a large portion of the continent with high biomass

60 yield potential, has been targeted for large scale lignocellulosic biomass production

61 (Alexopoulou et al., 2008; Keshwani and Cheng, 2009; Anderson and Sharp, 1995; Chen et al.,

62 2007; Montemayor et al., 2008 ). With 5-10 year average yields of 12-19 Mg/ha, switchgrass

63 has been at the forefront of biofuel biomass research (Burkhardt et al., 2015). Switchgrass has

64 been adopted to a range of climate and soil conditions from the northern U.S. to the Rocky

65 Mountain regions and Mexico (Mosel and Vogel, 1995; Hitchcock, 1971).

66 Rapeseed, an industrial oil seed crop, is relatively tolerant to stress conditions including saline

67 soils (Ashraf et al., 1990; He and Cramer, 1992). Grewal (2010) studied the response of wheat, 
barley (Hordeum vulgare, cv. Carla INTA), rapeseed (Hyola 42), and chickpea (Jimbour) to

69 variable levels of subsoil sodium chloride $(\mathrm{NaCl})$ and determined rapeseed to be the most

70 tolerant to $\mathrm{Na}^{+}$of the four crops. In rapeseed damage to plant tissues due to salt intake can

71 appear during all developmental stages including germination, seedling establishment, vegetative

72 growth, and seed production (Porcelli et al., 1995). Salt stress can also damage cell membranes

73 and inhibit photosynthetic functions (Munns and Tester, 2008) in the rapeseed crop.

74 While the effects of salinity on many edible and non-edible crops are widely reported in the

75 literature, the effects of the high organic content present in produced water on plant growth and

76 physiological characteristics are not well known. The specific impact of shale-gas-produced

77 water on plant health has not been studied. Burkhardt et al. (2015), Mullins and Hajek (1998),

78 and Vance et al. (2008) reported different dilutions of coalbed-methane-produced water used for

79 irrigation. Burkhardt et al. (2015) studied the effect of varying ratios of produced water and

80 municipal water on soil characteristics, and plant biomass and secondary metabolites of sweet

81 wormwood and switchgrass. They found increasing accumulation of $\mathrm{Na}^{+}$and salts in the soil

82 with increasing concentration of the produced water. An average produced water $\mathrm{Na}^{+}$

83 concentration of $1156 \mathrm{mg} / \mathrm{l}$ hampered plant growth.

84 Mullins and Hajek (1998) treated sorghum-sudangrass in a greenhouse study with varying

85 dilutions of produced and deionized water up to $2000 \mathrm{mg} / \mathrm{l}$ total dissolved solids based on limits

86 set by Alabama's Department of Environmental Management for irrigation water salinity, and

87 reported forage yield decreased due to water logging. Vance et al. (2008) studied soil properties

88 and vegetation responses resulting from one to four years of saline-sodic water with an EC range

89 of 1.6-4.8 ds/m applied on native range grasslands, seeded grass hay fields, and alfalfa hay fields

90 during two growing seasons. Biomass production was lower in fields irrigated with coal bed 
91 produced water. Zheljazkov and colleagues (2013) studied the effect of produced water from coal

92 bed methane production on spearmint (Mentha spicata L.) and peppermint (Mentha $\times$ piperita

93 L.). The low quality irrigation water adversely affected the soil quality and crop biomass yield by

$9450 \%$. The characteristics of coal bed methane produced water were greatly different than shale

95 gas produced water (Burkhardta et al., 2015), and the TOC concentration had not been noted.

96 The aim of the present study was to evaluate the response of switchgrass and rapeseed to treated

97 produced water as an irrigation water source. Given how little is known about the effects of shale

98 oil/gas produced water on plant growth and the growing interest to reuse produced water in

99 irrigation, it is paramount that we understand its effects on soil accumulation and plant health.

\section{2. Material/Methods}

\section{$101 \quad 2.1 \quad$ Water treatment processes}

102 To adjust the TDS and TOC concentrations of produced water to the four treatment levels, 103 dilution with CSU (Colorado State University) tap water and/or chemical treatment processes 104 was used. Treatment processes. Water quality of CSU tap water is derived from the surface water 105 and is given in Tables 1-3. Oxidation of $\mathrm{Fe}^{+2}$ to $\mathrm{Fe}^{+3}$, electrocoagulation (Water Tectonic, 106 Everett, WA), solid-liquid separation process (dissolved air flotation followed by hollow fiber 107 membrane ultrafiltration (Mann+Hummel, Germany), granular activated carbon for organic 108 matter removal were used to treat the produced water samples.

\subsection{Water characteristics}

110 The produced water used in this study was taken from a commercial central processing facility

111 that serves over 500 wells in the Denver-Julesburg Basin. Typically these water samples have 112 high TOC concentrations (>2000 mg/l) and TDS values in the range of 20,000 to 25,000 mg/l. In 
113 order to study the individual effects of these parameters on plants, best and worst case scenarios

114 were defined representing high TDS-TOC and low TDS-TOC, respectively. Also, two other

115 cases were defined to study the effects of the organic content of these waters. These water

116 qualities were achieved by treating produced water to different qualities through a sequence of

117 several treatment processes which included dilution with surface waters. Five different water

118 qualities were chosen:

\section{A. Horsetooth Reservoir water}

120

This water source was used as a control treatment. TDS and TOC levels of control water were $310 \mathrm{mg} / \mathrm{l}$ and $3.3 \mathrm{mg} / \mathrm{l}$, respectively. All the results will be compared to the control experiments.

B. Best quality produced water: low TDS $(400 \mathrm{mg} / \mathrm{l})$ and low TOC $(<5 \mathrm{mg} / \mathrm{L})$. To generate high quality water for irrigation, effluent of a coagulation/ultrafiltration (UF) process is treated with granular activated carbon (GAC) and then diluted using CSU tap water to a TDS level of $400 \mathrm{mg} / \mathrm{l}$. The TOC concentration of this sample was under $3 \mathrm{mg} / \mathrm{l}$.

C. Medium salt $\mathrm{TDS}=3500 \mathrm{mg} / \mathrm{l}$ and low organic matter concentration. content of water at a constant TDS concentration $(3,500 \mathrm{mg} / \mathrm{l})$ and vary the TOC value. For this aim the effluent of the GAC column was diluted with CSU tap water to reach the TDS level of 3,500mg/l. TOC concentrations for these samples varied from $65 \mathrm{mg} / 1$ to $100 \mathrm{mg} / 1$.

D. Medium salt TDS $=3500 \mathrm{mg} / \mathrm{l}$ and high organic matter concentration. 
Dilution of coagulation/UF effluent with CSU tap water to a TDS level of 3,500 mg/l was used to obtain high organic content water with TDS level of 3500mg/l. TOC concentration of these waters varied between $215 \mathrm{mg} / \mathrm{l}$ and $235 \mathrm{mg} / \mathrm{l}$.

E. Cleaned brine: high TDS and high TOC

A pretreatment method was used to remove suspended solids. To generate this water quality several treatment process included $\mathrm{H}_{2} \mathrm{O}_{2} / \mathrm{EC} / \mathrm{UF}$ (oxidation with $\mathrm{H}_{2} \mathrm{O}_{2}$ followed by coagulation and filtration) were used. The TDS concentration was in the range of 15,000 to $20,000 \mathrm{mg} / 1$ and the TOC concentration was approximately $1,500 \mathrm{mg} / \mathrm{l}$.

The purpose of these four water qualities was to determine minimal water quality and treatment required for sustainable biomass growth using produced water. Table 1 through 3 show different characteristics of water samples with standard error (SE) used for irrigation of the rapeseed and switchgrass crops during the 106-day experiment.

\subsection{Plant material}

Seeds of switchgrass and rapeseed cultivars were purchased from Midwest Laboratories (Omaha NE 68144) and were stored at $4{ }^{\circ} \mathrm{C}$ prior to initiation of experiments.

\subsection{Seed germination experiment}

To evaluate the influence of produced water quality on germination efficiency and seedling emergence rate, seeds were planted in germination boxes placed in growth chambers according to Anderson et al. (2012). Seeds of both species were sown in $10 \mathrm{~cm}$ diameter Petri dishes on two layers of blue seed germination blotter (Anchor, St. Paul, MN, USA) and imbibed with $15 \mathrm{~mL}$ of liquid from each water treatment solution. The Petri dishes were sealed tightly with Parafilm to prevent evaporation. Three replications with 25 seeds of each switchgrass and rapeseed were used for each of the five treatments (Tables 1-3). Seeds in the Petri dishes were incubated in a 
157 programmed germination chamber (VWR international, Cornelius, OR, USA) at $18{ }^{\circ} \mathrm{C}$ dark/30

$158{ }^{\circ} \mathrm{C}$ light with 16 hour photoperiod (light photon flux density: $25 \mu \mathrm{m}$ photon $\mathrm{m}^{-2} \mathrm{~s}^{-1}, 380-680 \mathrm{~nm}$ ).

159 All dishes were randomly arranged inside the growth chamber. Germinated seeds were counted

160 at $2 \mathrm{~d}$ intervals for 21 days. A seed was counted as germinated when the seed coat was broken

161 and the radical emerged. The relative seed germination percentage for each treatment was

162 calculated by dividing the number of germinated seeds in the test solution by number of 163 germinated seeds in the control solution.

164 The seedling germination rate was estimated using a modified Timson Index:

165 Germination rate $=\sum G / t$

166 Where $\mathrm{G}$ is the percentage of seed germination at 2-day intervals and $\mathrm{t}$ is the total germination

167 period (Whitney, 1988; Khan and Ungar, 1984; Timson, 1964). The greater the value the more 168 rapid the rate of germination.

$169 \quad 2.5$ Greenhouse plant growth study

170 A crop growth study was performed in a heated and humidified greenhouse at Colorado State

171 University to evaluate the feasibility of flowback and produced water for irrigation on the 172 switchgrass and rapeseed crops. The greenhouse temperature varied in the range of $22 \pm 3{ }^{\circ} \mathrm{C}$, 173 relative humidity was adjusted to vary between 50 and 70\%, and light exposure was about $10 \mathrm{~h}$ 174 per day. Seeds were sown into one-inch deep holes in $40 \mathrm{~cm}$ diameter round pots in mid175 December 2015 and the plants were harvested the first week of April 2016. A total of 30 pots 176 including 15 rapeseed and 15 switchgrass were studied. The pots were randomly arranged in one 177 block of 15 pots of each species, with three replicates for each treatment. To avoid boundary 178 edge effects due to radiation variation from differences in shading on each treatment, barrier 
179 layers of extra planted pots were placed between the two crop species and around the perimeter

180 of the three blocks of treatment pots. During the first five weeks after planting, the pots were

181 irrigated with water from Horsetooth Reservoir. For the remainder of the experiment, plants were

182 irrigated using five different qualities of treated hydraulic fracturing produced water. The

183 irrigation frequency was three times a week for 20 minutes during establishment and during the

184 treatment application period.

\subsection{Biomass measurements}

186 At the end of plant growth period (106 days), all the plants were cut $2 \mathrm{~cm}$ above of the soil

187 surface, put in paper bags, dried at $60{ }^{\circ} \mathrm{C}$ for 48 hours, and weighed to determine above ground

188 biomass. Since the rapeseed plant is an annual, roots were also pulled out of the soil, and rinsed

189 with DI water, and dried as described above. Switchgrass plant crowns and roots were not

190 removed and left in the pots for a second growth cycle.

$191 \quad 2.7$ Physiological measurements

192 At the end of the experiments on day 106, physiological measurements were performed on

193 harvested shoots and the above ground biomass of both species, and rapeseed roots. Plant 194 survival, height, growth, and biomass were measured for each pot. Scanning electron microscopy 195 was done on the leaves of rapeseed and switchgrass. Leaf firing percentage was determined 196 weekly by visually estimating the burned leaf area as an indication of salt injury (Kim et al., 197 2012). A 1 to 9 visual rating scale is used with 1 being complete wilting, 100\% leaf firing, 198 complete dormancy or no plant recovery; and 9 being no wilting, no leaf firing, 100\% green-no 199 dormancy, or $100 \%$ recovery. Plant survival was determined based on the presence of one or 200 more green tillers for each pot at the time of harvest. Leaf electrolyte leakage (leaf EL) was 201 measured according to the method of Marcum (Morris et al., 1998) with some modifications. The 
202 top second third of switchgrass and rapeseed mature leaves were cut into 2-cm segments. After 203 being rinsed three times with distilled water, $0.2 \mathrm{~g}$ of leaf segments were placed in a plastic tube 204 containing $20 \mathrm{~mL}$ of distilled water. The test tubes were agitated on a shaker for 24 hour and the 205 solution conductivity (C1) was measured with a conductivity meter SR60IC (VWR International, 206 PA USA). Leaf samples were autoclaved at $120{ }^{\circ} \mathrm{C}$ for $30 \mathrm{~min}$, and the conductivity of the 207 solutions containing killed tissue were measured (C2). The relative leaf EL was calculated as $208(\mathrm{C} 1 / \mathrm{C} 2) \times 100$.

209 Oven dried roots and shoots were ground using a mechanical grinder to pass through a screen 210 with $425 \mu \mathrm{m}$ openings. Mineral analyses including $\mathrm{Na}, \mathrm{K}, \mathrm{Mg}$ and $\mathrm{Ca}$ were conducted on ground 211 roots and shoots using a SpectrAA 40 atomic absorption spectrometer (Varian Analytical 212 Instrument, Palo Alto, CA). The selectiveness of ion accumulation for $\mathrm{K}^{+}$over $\mathrm{Na}^{+}$was 213 estimated from ion content according to the following equation (Marcum, et al., 1998):

214 Selectiveness $\mathrm{S}=\left[\mathrm{K}^{+} / \mathrm{K}^{+}+\mathrm{Na}^{+}\right]$leaves $/\left[\mathrm{K}^{+} / \mathrm{K}^{+}+\mathrm{Na}^{+}\right]$medium

215 The higher $\mathrm{S}$ value indicates a greater selectivity absorption capacity that excluded $\mathrm{Na}^{+}$and 216 absorbed $\mathrm{K}^{+}$by either the shoot or root system.

217 The salt crystals on the surface of adaxial leaves in switchgrass and rapeseed at $33.8 \mathrm{ds} / \mathrm{m}$ EC 218 were examined with scanning electron microscopy (JEOL JSM-6500F field emission scanning 219 electron microscope, Massachusetts, USA). Three of the first fully extended mature leaves, that 220 were the fourth leaves from apex, were selected for microscopic investigation. 


\section{$222 \quad 2.8$ Organic analyses}

223 Fresh plant tissues of both rapeseed and switchgrass were cut into $2 \mathrm{~cm}$ segments and frozen at $22420{ }^{\circ} \mathrm{C}$ until the day of extraction and analyses. Total nitrogen $(\mathrm{N})$ and Total carbon $(\mathrm{C})$ were 225 analyzed with a Leco FP-528 (Horneck and Miller, 1998) and Leco Chn analyzer (Saint Joseph, 226 MI, USA), respectively. Soluble carbohydrate (glucose, fructose, and sucrose) analyses were

227 conducted on switchgrass and rapeseed shoots based on Smith (1969). Carbohydrates and lignin 228 were determined using a sequential procedure described by Soil, Water and Plant Testing 229 Laboratory at CSU. Briefly, soluble carbohydrates were extracted with 80\% (vol/vol) ethanol 230 and analyzed by a colorimetric method by Smith et al. (1969) using a Thermo spintronic 231 scientific 20Dplus (Madison, WI, USA).

$232 \quad 2.9$ Water quality analysis

233 All water quality analyses were done using Standard Method procedures (2013). TOC, 234 gravimetric TDS and $\mathrm{pH}$ analyses were conducted at the Colorado State University 235 Environmental Engineering water quality laboratory. An independent, EPA certified laboratory 236 provided analysis of cations and anions. Gravimetric TDS was measured based on standard 237 methods of water and wastewater developed by American Public Health Association and 238 American Water Works Association, Water Pollution Control Federation, and Water 239 Environment Federation. The ionic TDS concentration was calculated by summing the anion and 240 cation concentrations. A Hach HQ40d pH meter (Hach, Loveland) was used to measure $\mathrm{pH}$ in 241 samples. Also, TOC was measured using Standard Methods 2540D 5130B. Cations were 242 measured by EPA 2007 method 6010 C using a Varian ICP-AES, Liberty, California, USA. 
244 The soil used in this study was a clay loam. Soil properties are shown in Table 4. Cations and 245 anions, GRO, DRO, and BTEX were measured.

246 Analysis of the soils was done by the Soil, Water and Plant Testing Laboratory at CSU, Fort

247 Collins, CO after plant harvest. Methods used for soil analysis were as follows: pH using a 1:1 248 saturated paste according to Watson and Brown (1998); nitrate according to Carson (1980); EC 249 and soluble salts using the saturated 1:1 paste according to Dahnke and Whitney (1988); SAR 250 was done according to procedures defined by United States Salinity Laboratory Staff (1954); P 251 was measured using the bicarbonate method (Richards, 1954); and sulfate, $\mathrm{K}, \mathrm{Ca}, \mathrm{Mg}$, and $\mathrm{Na}$ by 252 Brown and Warncke (1988). Micronutrients (Zn, Fe, Mn, $\mathrm{Cu}$, and B) were quantified according 253 to Whitney (1988).

254 At the end of the growing cycle, the soils of the rapeseed pots were mixed and subsamples were 255 taken from each pot at root depth for compounds of interest including BTEX, gasoline and diesel 256 range hydrocarbons using purge and trap and methanol extraction methods by LC-MS and GC257 MS following SW-8260 and 5035.

\subsection{Statistical Analyses}

260 The plant growth experiments were a $2 \cdot 5$ factorial design (two crop species and five water 261 qualities, respectively). All data were subjected to analysis of variance (ANOVA), with the 262 measured effects of water quality, species, and interaction of water quality $\times$ species (SAS 8.1, 263 SAS Institute Inc., Cary, NC). Seed germination percentages were conducted as a $2 \cdot 5$ factorial 264 combination as above. Seedling rate of germination conducted as a $2 \cdot 5$ factorial with the 
265 measured effects of water quality, species, time, and interactions of water quality $\times$ species,

266 species $\times$ time, water quality $\times$ time, and water quality $\times$ species $\times$ time. Whenever interactions

267 are not important, the main factors are discussed. The main effects of each treatment were

268 considered significant if $p \leq 0.05$, unless otherwise indicated. Mean separations were done using

269 Tukey Pairwise Comparisons when ANOVA indicated there is a difference between treatments

270 or interactions.

\section{3. Results/Discussion}

272 3.1Seed germination

273 Switchgrass and rapeseed seed germination percentages were both adversely affected by

274 increasing salinity concentration $(p<0.0001)$, with rapeseed being more tolerant to salinity and

275 TOC concentration than switchgrass (Figure 1). For both species, water quality E with EC =

$27634.4 \mathrm{ds} / \mathrm{m}$ and $\mathrm{TOC}=1352 \mathrm{mg} / \mathrm{l}$ led to less than $5 \%$ seedling emergence, as was expected

277 (Anderson et al., 2015; Kim et al., 2012; Kim et al., 2012). It is important to note that the higher

278 TOC concentration $(\mathrm{TOC}=232 \mathrm{mg} / \mathrm{l})$ in water quality $\mathrm{D}$ versus water quality $\mathrm{C}(\mathrm{TOC}=38$

$279 \mathrm{mg} / \mathrm{l}$ ) resulted in a significant decrease in the number of germinated seeds in both rapeseed and 280 switchgrass (Table5).

281 There was a significant correlation between salinity and both germination rates and relative 282 germination rate estimated by the Timson Index $\left(r^{2}=0.69, p<0.0001\right.$, and $\left.r^{2}=0.6, p<0.0001\right)$.

283 Germination rate and relative germination were also highly correlated $\left(r^{2}=0.88, p<0.0001\right)$.

284 As Figure 2 illustrates, the rapeseed seed germination rate was more rapid than switchgrass 285 across all water quality treatments. The rate in irrigation water D dropped by $50 \%$ compared to 286 irrigation water $\mathrm{C}$, indicating the importance of the produced water derived organic matter 
287 concentration in irrigation water samples on germination rate and also the number of germinated 288 seeds.

290 Although irrigation waters except irrigation water $\mathrm{E}$ resulted in no difference in relative 291 germination percentages for both switchgrass, and canola, there were differences in germination

292 rates (Table 5). There was no difference among control water and irrigation water B and C 293 regarding relative germination and germination rate for either species (Table 5). However, 294 irrigation water $\mathrm{D}$ and $\mathrm{E}$ were both different than the other water qualities, confirming the 295 observation of strong negative influence of TOC on the seeds emergence and the germination 296 rate of switchgrass and rapeseed species. This is an important observation regarding the high 297 organic concentration of produced water and its influence on germination rate. Irrigation water 298 E, with the highest EC and TOC values, not surprisingly showed the lowest germination rate and 299 relative germination percentages for either species. These results suggest that when establishing 300 new crops, poorer quality produced water should not be used.

$301 \quad 3.2$ Soil analyses

$302 \quad 3.2 .1$ Organic

303 Only soils from the rapeseed pots were analyzed for BTEX compounds, diesel range organics $304\left(\mathrm{C}_{10}-\mathrm{C}_{28}\right)$ and gasoline range organics $\left(\mathrm{C}_{6}-\mathrm{C}_{12}\right)$. Switchgrass crops will be studied for the second 305 growth, therefore soils from those pots were not analyzed. None of these organic compounds 306 were detected in any of the soil samples. Biodegradation or volatilization of BTEX compounds 307 likely occurred in all four of the soil sample types. Biodegradation of BTEX has been well 308 studied (Debez et al., 2004; Farhadin et al., 2008; Young et al., 2005; Beller et al., 1995; 
309 Chakraborty et al., 2004; Cunningham et al., 2001) and can occur within the time period of the 310 growing cycle.

311 3.2.2Mineral

312 Electroconductivity of the soil at the end of the growing cycle (day 106) was plotted versus the

313 irrigation water quality type (A-E) for each of five treatments in Figure 3 . Soil 314 electroconductivity increased compared to initial soil measurements collected before starting the 315 experiments (Fig. 2).

317 At the end of 106 days, the EC of soil samples of all five treatments (including the control) were 318 higher than the EC of virgin soil $(0.5 \mathrm{ds} / \mathrm{m}$, Table 4$)$. The salt accumulation in soils of rapeseed 319 and switchgrass pots was relatively low and stable except for irrigation water E (maximum EC $32033.8 \mathrm{ds} / \mathrm{m})$. Not surprising, maximum soil EC was observed in irrigation water $\mathrm{E}$ for both 321 rapeseed and switchgrass at $16 \mathrm{ds} / \mathrm{m}$ and $18 \mathrm{ds} / \mathrm{m}$, respectively.

322 There were significant differences for soil EC between irrigation water E and the rest of the 323 irrigation waters, with EC increasing to $17 \mathrm{ds} / \mathrm{m}$ and $22 \mathrm{ds} / \mathrm{m}$ for rapeseed and switchgrass, 324 respectively (Table 7). Means that do not share a letter are significantly different. As expected, 325 the organic content of irrigation water seemed to not have an effect on soil EC when comparing 326 irrigation water C and irrigation water D. Also, salt accumulation in the switchgrass samples was 327 greater than the rapeseed soil samples. This could be due to less growth of crops in the 328 switchgrass pots (less biomass) and/or measurement errors (different depth/ spot) in the pots. 
330 Soil characteristics of rapeseed pots were analyzed for $\mathrm{Na}^{+}, \mathrm{K}^{+}, \mathrm{Mg}^{+2}, \mathrm{Ca}^{+2}, \mathrm{Sr}^{+2}$ and boron at the 331 end of the 106-day growing cycle (Figure 4). Water quality was only significant for Na and 332 boron accumulation $(p<0.0001)$. At the end of 106 days, there was a significant difference in 333 boron concentration between soil $\mathrm{E}$ and the rest of the soil samples with $\mathrm{B}$ concentration being 334 zero in virgin soil and soil A, B, C and D (Figure 4).

335 There was no difference among all five treatments at the end of 106 days, except B

336 Accumulation of boron in soil $\mathrm{E}$ with $17 \mathrm{mg} / \mathrm{kg}$ is due to the high concentration $\left(\mathrm{B}^{+3}=22 \mathrm{mg} / \mathrm{l}\right)$ of 337 boron in the produced water sample $\mathrm{E}$ (Table 3 ). $\mathrm{Na}^{+}$accumulation was obvious at the end of 338106 days for soils B, C, D and E with soil E having the highest concentration at $6400 \mathrm{mg} / \mathrm{kg}$. $339 \mathrm{Ca}^{+2}$ and $\mathrm{Mg}^{+2}$ concentrations did not change after irrigation with any of the five water types. $340 \mathrm{Sr}^{+2}$ concentrations in irrigated soils were also higher than virgin and control soils, indicating 341 accumulation of $\mathrm{Sr}^{+2}$ in soil samples due to high occurrence in the irrigation waters (treated 342 produced water). This is more pronounced in soil E with $\mathrm{Sr}$ concentration at $143.3 \mathrm{mg} / \mathrm{kg}$ 343 compared to $110 \mathrm{mg} / \mathrm{kg}$ in virgin soil.

\section{3.3Physiological characteristics}

345 Water quality stress on the crop species was statistically significant $(P \leq 0.05)$ for electrolyte 346 leakage (EL) and plant height. The interaction of these factors was only significant for plant 347 height. The effects of produced water quality on biomass production and physiological 348 characteristics of rapeseed and switchgrass are discussed below.

$349 \quad$ 3.3.1Plant growth and biomass yield

350 Effect of water quality on switchgrass and rapeseed biomass is shown in Figure 5. All plants in 351 all treatments survived until harvest. Rapeseed and switchgrass had very similar growth response 
352 patterns for the four produced water irrigation water qualities compared to the control water.

353 Plant growth parameters including aboveground biomass and plant height (for rapeseed and 354 switchgrass) and belowground biomass (for rapeseed) were reduced when the plants were 355 irrigated with irrigation water E containing very high salinity and organic content (Figure 5). 356 These results agree with previous studies such as those of Kim et al. (2012a and 2012b), 357 Anderson et al. (2015), Grewal et al. (2010), and Bilgili et al. (2011) where they reported saline 358 waters (EC range in $10 \mathrm{ds} / \mathrm{m}-14 \mathrm{ds} / \mathrm{m}$ ) greatly influenced biomass production of switchgrass and 359 rapeseed. With increasing salinity and TOC concentration of the irrigation water, the decrease of 360 root and height biomass in switchgrass were higher than those in rapeseed. The ratio of 361 root/shoot biomass of rapeseed increased with increasing salinity, a result consistent with 362 previous work on rapeseed by Bilgili et al., (2011).

364 Crop species and water quality were significant for plant height $(p=0.001)$ while species was 365 not significant for biomass yield. Also water quality had a significant effect on biomass of 366 rapeseed and switchgrass, and below ground biomass and shoot to root ratio of rapeseed $(p<$ 367 0.0001). Pop $\times$ TDS (interaction) was significant only for plant height.

368 For both rapeseed and switchgrass, plant height was highly correlated with above ground 369 biomass dry weight with $r=0.62$ and $p<0.0001$ and $r=0.69$ and $p<0.0001$, respectively. The 370 analysis of variance revealed that there were significant negative correlations among growth 371 parameters including biomass and height, and irrigation water treatments with $r=-0.798, p<$ 3720.0001 and $r=-0.534, p<0.0001$, respectively. 
373 High salinity and TOC levels of irrigation water $\mathrm{E}(\mathrm{EC}=34.4 \mathrm{ds} / \mathrm{m}$ and $\mathrm{TOC}=1352 \mathrm{mg} / \mathrm{l})$

374 significantly affected the switchgrass biomass yield, decreasing from $47 \mathrm{~g}$ with irrigation water A

375 (control) down to one eighth of that at 5.9g with irrigation water E (Figure 5a). This response

376 was similar to the response seen for rapeseed with $86 \%$ above ground biomass reduction (Figure

377 5a). It is important to note that there was also a significant difference on biomass production

378 (30\% reduction) between irrigation water $\mathrm{C}$ and irrigation water $\mathrm{D}$. In other words, the greater

379 the produced water organic matter concentration (TOC) in the irrigation water, the less biomass

380 was produced (treatment D compared to treatment C). This significant difference between the

381 two irrigation waters explicitly shows the importance of treatment and removal of the organic

382 matter in produced water.

383 Table 6 and Table 7 show the analysis of means by ANOVA for plant physiological parameters

384 when averaged across treatments and species, respectively. No difference was detected among

385 the species for above ground biomass when averaged across all treatment levels (Table 6). Plants

386 treated with water with the highest EC and TOC (irrigation water E) were significantly shorter

387 than those irrigated with all other waters and were affected by leaf firing at early stages (Table

388 7). The higher organic content of irrigation water D compared to irrigation water C, significantly

389 increased the leaf electrolyte leakage and decreased both the above ground and underground

390 biomass yield (Table 7) when averaged over water quality levels. With increasing salinity,

391 rapeseed root and shoot and switchgrass shoot biomass decreased. Visual observations revealed

392 more developed root mass in control pots with decreasing development with increasing salt

393 concentration (data not shown). The ratio of root/shoot for rapeseed crops decreased with

394 increasing salinity amount in the water treatments (Figure 5d). These results are consistent with 
395 previous studies (Kim et al., 2012; Burkhardt et al., 2015; Porcelli et al., 1995; Grewal, 2010;

396 Sanderson et al., 1996).

397 Based on these results, switchgrass yields more biomass weight with the same irrigation water 398 quality and seemed to be less sensitive to poorer water quality, indicating that selection of plant 399 species should be considered when using treated produced water for irrigation. Rapeseed 400 aboveground biomass was not affected when using irrigation waters A, B, C and D as the salt 401 concentration in the soil and water increased (below $5.47 \mathrm{ds} / \mathrm{m}$ ) (Table 6). This is in agreement 402 with data from Porcelli (1995), Francois et al. (1994), and Boem et al. (1994), who had found no 403 effect of salinity up to $10 \mathrm{ds} / \mathrm{m}$. However, irrigation water E resulted in a significant decrease in 404 biomass production with salinity at $33.8 \mathrm{ds} / \mathrm{m}$. Irrigation water D resulted in significantly lower 405 above and below ground rapeseed biomass yields when compared to treatment $\mathrm{C}$, a result 406 attributed to the greater TOC concentration (salinity concentrations were equal, Table 7). This 407 observation can be explained as the higher concentration of produced water organic compounds 408 in irrigation water D resulted in higher cell damage of plants species, higher leaf EL, and less 409 growth rate and is confirmed in literature (Bilgili et al., 2011; Francois et al., 1994; Liu et al., 410 2014).

411 Although irrigation water B had undergone more treatment processes and contained less salinity 412 and TOC than irrigation water $\mathrm{C}$, there was not a difference between irrigation water $\mathrm{B}$ and 413 irrigation water $\mathrm{C}$ in plant height, above ground biomass, underground biomass or shoot to root 414 ratio. It is important to point out that treating produced water to the quality of irrigation water B 415 is both time consuming and costly and based on these results, irrigation water $\mathrm{C}$ may be 416 sufficient. This remark is of importance in reusing produced water in irrigation of non-food 417 biofuel crops such as rapeseed and switchgrass. Also, establishing treatment requirements for 
418 produced water should be based on removal of salts as well as organic matter, due to the

419 significant influence of TOC concentration of irrigation water on the plants health and

420 physiological parameters and biomass yield.

421 Based on the physiological characteristics of switchgrass and rapeseed and the germination

422 study, it can be concluded that the rapeseed crop was more tolerant to poor quality treated

423 produced water than switchgrass and biomass production was not affected by the irrigation water

424 quality. This is an important observation as application of produced water for irrigation is being

425 evaluated in multiple shale plays. According to these results, treatment processes that would

426 provide TOC removal to less than $5 \mathrm{mg} / \mathrm{l}$ is necessary for irrigation of nonfood biofuel crops with

427 hydraulic fracturing-related produced water.

428 Figure 6 shows salt crystals on the leaf surfaces of rapeseed and switchgrass treated with

429 irrigation water E, and also adaxial salt glands. Abaxial salt glands were often found in the same 430 row with stomata, and adaxial salt glands were located on the walls of ridges, as shown in the 431 leaf cross section of switchgrass (Figure 6a and 6b).

432 3.3.2Leaf EL

433 Leaf electrolyte leakage is a good indication of plant response to an environmental stress. 434 Measurement of this phenomenon is commonly used to evaluate the tolerance of crops to stress 435 conditions such as draught, harsh temperatures, and salinity. The results are shown in Figure 7. 436 Associated TDS and TOC values are shown in Tables 1, 2 and 3.

437 According to Figure 7, the leaf EL of both rapeseed and switchgrass increased rapidly with 438 increasing salinity and TOC concentration of the water. All four produced water qualities 439 resulted in significantly higher EL values than the control for both rapeseed and switchgrass. 
440 However, the leaf EL was significantly lower for switchgrass with $28.5 \%$, compared to $35.5 \%$

441 for rapeseed when averaged over treatments (Table 6). These values are within the range of

442 reported leaf EL values (Kim et al., 2012; Blum and Ebercon, 1981). By the end of the irrigation

443 season, EL for irrigation water E was more than 3 and 5 times the control level for rapeseed and

444 switchgrass, respectively. The high organic content of irrigation water D relative to irrigation

445 water C (they have equivalent TDS concentrations) significantly increased the leaf EL on both

446 rapeseed and switchgrass species, which shows greater damage to cell membranes for this stress

447 condition (contaminations of irrigation water by high organic loads). Based on the results, leaf

448 EL of switchgrass was $45 \%$ when treated with significantly higher TOC water compared to $30 \%$

449 when it was treated with water with the same EC and lower TOC level. The amount of 450 electrolyte leakage of rapeseed at treatment $\mathrm{EC}=5.5 \mathrm{ds} / \mathrm{m}$ and $\mathrm{TOC}=35.8 \mathrm{mg} / \mathrm{l}$ is higher than 451 values reported by Farhoudi et al. (2011) which could be due to the organic content of irrigation 452 water in this study.

453 For both switchgrass and rapeseed, water quality was significant for leaf EC $(p<0.0001, p<$ 454 0.0001). Analyses of the mean showed a significantly high correlation between leaf electrolyte 455 and irrigation water quality (TOC and TDS) with $r^{2}=0.83$ and $p<0.0001$. Leaf electrolyte values 456 significantly decreased from irrigation water A (control) to irrigation water $\mathrm{E}$ when averaged 457 over both plant species (Table 7). These results confirm the impacts of organic content of the 458 irrigation water on both rapeseed and switchgrass species with equivalent salinity values 459 (irrigation waters C and D). Based on Figure 7 and Table 7, high TOC concentration was the 460 stress factor, resulting in higher damage in cell membranes and ultimately higher EL values. 461 These observations can be used as guidance for regulators and stakeholders in development of 462 treatment standards in which organic matter should be removed to less than $50 \mathrm{mg} / \mathrm{l}$ to keep leaf 
463 EL (cell damage) to less than $50 \%$ and a TOC concentration of less than $5 \mathrm{mg} / \mathrm{l}$ required to keep a 464 sustainable biomass production rate.

465 3.3Plant uptake

$466 \quad 3.3 .1$ Organic

467 None of the BTEX, DRO and GRO compounds were detected in any of the samples. This could 468 be explained as high biodegradability and the lack of accumulation of these compounds in the 469 soils.

$470 \quad$ 3.3.2 Inorganic

$471 \mathrm{Na}^{+}, \mathrm{K}^{+}, \mathrm{Mg}^{+2}, \mathrm{Ca}^{+2}, \mathrm{Sr}^{+2}$ and boron content of plant tissue of both rapeseed and switchgrass 472 crops were measured. Figures 8 and 9 illustrate the mineral uptake of five cations, $\mathrm{Na}^{+}, \mathrm{K}^{+}$, $473 \mathrm{Mg}^{+2}, \mathrm{Ca}^{+2}, \mathrm{Sr}^{+2}$ and one anion, boron for both crop species. There was no clear trend either 474 within or between species with respect to the studied monovalent cations. There were no 475 significant changes in $\mathrm{Na}^{+}$and $\mathrm{K}^{+}$contents in shoot biomass of both switchgrass and rapeseed at 476 all levels of salinity $(P=0.169)$. According to Figure 8 and the ANOVA, neither species nor 477 irrigation water quality were significant for $\mathrm{Na}, \mathrm{K}$ or $\mathrm{Na} / \mathrm{K}$.

478 There was no clear trend in selectiveness between switchgrass and rapeseed in above ground 479 tissues. Below ground tissue analysis revealed positive correlations between $\mathrm{Na}$ and $\mathrm{Ca}, \mathrm{K}, \mathrm{Sr}$, 480 and $\mathrm{Mg}\left(r^{2}=0.78,0.71,0.81\right.$ and 0.85 , respectively, all at $\left.P<0.005\right)$ but only weak or no 481 correlations in above ground tissues. There was a slight difference between plant uptake of both 482 rapeseed and switchgrass for monovalent cations of $\mathrm{Na}$ and $\mathrm{K}$, which is associated with salt 483 accumulation with irrigation water E. 
485 Effects of salinity and organic content from four different produced water irrigation water 486 samples plus the control water on the $\mathrm{Ca}^{+2}, \mathrm{Mg}^{+2}$ and $\mathrm{Sr}^{+2}$ content of rapeseed and switchgrass

487 are shown in Figure 9. Plant uptake for these divalent ions was constant through all irrigation 488 treatments. For all studied ions, plant uptake of both rapeseed and switchgrass was higher than 489 the associated measured concentrations in irrigation water samples (Table 2). Based on Figure 9, 490 high occurrence of $\mathrm{Mg}^{+2}$ and $\mathrm{Ca}^{+2}$ in plant tissues can be related to high concentrations of $\mathrm{Ca}^{+2}$ 491 and $\mathrm{Mg}^{+2}$ in the virgin soil (Figure 4), since there was very low concentration of $\mathrm{Ca}$ and $\mathrm{Mg}$ in 492 irrigation waters (Table 2). Although Sr concentration was negligible in all irrigation waters 493 except irrigation water $\mathrm{E}$ with $\mathrm{Sr}=37 \mathrm{mg} / \mathrm{l}$ (Table 2), plant uptake was constant for all irrigation 494 waters at approximately $29 \mathrm{mg} / \mathrm{kg}$ to $36 \mathrm{mg} / \mathrm{kg}$. This can be explained by higher $\mathrm{Sr}$ 495 concentrations in the virgin soil samples (Figure 4).

496 4. Conclusion

497 This study demonstrated the impacts of produced water reuse in irrigation of rapeseed and 498 switchgrass, two non-food biofuel crops known to have some degree of salt tolerance. A 499 greenhouse study on rapeseed and switchgrass for one growing season was conducted. In this 500 study, seedling emergence, biomass yield plant health were evaluated under high organic content 501 of produced water including BTEX compounds as well as high salinity. Plant health, growth, and 502 physiological parameters were measured. Four different water qualities were developed from oil 503 and gas produced water through different levels of advanced treatment resulting in a range of 504 TDS and TOC concentrations were compared to a typical surface-source irrigation water control.

505 For both rapeseed and switchgrass, biomass yield and plant growth decreased as the quality of 506 water decreased due to an increase in salinity and TOC of treatments water qualities. There were 507 statistically significant differences between the irrigation water with highest TOC and EC rate 
$508(\mathrm{TOC}=1352 \mathrm{mg} / \mathrm{l}, \mathrm{EC}=33.8 \mathrm{ds} / \mathrm{m})$ and all other irrigation water treatments with lower EC and 509 TOCs. Salt accumulation in soil samples of rapeseed showed significant correlation with water 510 quality. These were clearly very important features for establishment and persistence of 511 perennial energy crops on marginal land affected by salinity. At a constant salinity of $5.47 \mathrm{ds} / \mathrm{m}$ 512 (irrigation water $\mathrm{C}$ and D) and TOC levels of $<232.3 \mathrm{mg} / \mathrm{l}$, compared to TOC of $38.3 \mathrm{mg} / 1 \mathrm{in}$ 513 irrigation water, rapeseed and switchgrass physiological parameters such as above ground and 514 underground biomass production were significantly affected. High TOC levels were shown to 515 affect the leaf EL value, which confirms the fact that these crop species are less tolerant to TOC 516 levels from produced water than to low concentrations found in irrigation waters. Thus, organic 517 level of produced water is as important factor as salinity level, if not more. The results indicated 518 that treated produced water to TDS level of $3500 \mathrm{mg} / \mathrm{l}$ and low organic content, necessary in 519 order to maintain the biomass yield and plant health of both rapeseed and switchgrass. Also it 520 was concluded that treating produced water to medium TDS of 3500mg/l and low TOC level is 521 the optimum treatment regarding cost, scalability and feasibility of reusing produced water in 522 irrigation activities. Not only salinity but also high TOC concentration was the stress factor, 523 resulting in higher damage in cell membranes (high EL values) and less biomass production. The 524 target quality of produced water dictates the cost of treatment and is ultimately a key parameter 525 in the adoption of produced water as an alternative to freshwater resources. These observations 526 can be used as guidance for regulators and stakeholders in development of treatment standards in 527 which organic matter should be removed to less than $50 \mathrm{mg} / \mathrm{l}$ to keep leaf EL (cell damage) to 528 less than $50 \%$ and a TOC concentration of less than $5 \mathrm{mg} / \mathrm{l}$ required to keep a sustainable biomass 529 production rate. 


\section{Acknowledgement}

532 The research described in this paper was funded by the National Science Foundation, NSF, 533 [grant 004180-00002]. Authors would like to thank Dr. Ann Hess, Department of Statistics, 534 Colorado State University, for her support on statistical analyses.

535

536

537

538

539

540

541

542

\section{References}

544

545 1. Esmaeilirad, N.; Carlson, K.; Ozbek, P.O. Influence of softening sequencing on 546 electrocoagulation treatment of produced water. Journal of hazardous materials, 2015.283 , $547 \quad$ pp.721-729.

548 2. Boysen, D.; Boysen, J.; Larson, T. Produced water management handbook. GRI-03-0016. 549 Gas Research Institute, II. 2011. 
3. Frohlich, C. Two-year survey comparing earthquake activity and injection-well locations in the Barnett Shale, Texas. Proceedings of the National Academy of Sciences, 2012. 109(35), pp.13934-13938.

4. Nicholson, C.; Wesson, R.L. Earthquake hazard associated with deep well injection. 1990.

5. Ellsworth, W.L. Injection-induced earthquakes. Science, 2013, 341(6142), p.1225942.

6. Keranen, K.M.; Savage, H.M.; Abers, G.A.; Cochran, E.S. Potentially induced earthquakes in Oklahoma, USA: Links between wastewater injection and the $2011 \mathrm{Mw} 5.7$ earthquake sequence. Geology, 2013. 41(6), pp.699-702.

7. Boschee, P. Handling Produced Water from Hydraulic Fracturing. Oil and Gas Facilities, 2012. 1(01), pp.22-26.

8. World Energy Outlook, International Energy Agency (IEA), 2012.

9. Alexopoulou, E.; Sharma, N.; Papatheohari, Y.; Christou, M.; Piscioneri, I.; Panoutsou, C.; Pignatelli, V. Biomass yields for upland and lowland switchgrass varieties grown in the Mediterranean region. Biomass Bioenergy, 2008. 32:926-933.

10. Lee, D.K.; Doolittle, J.J.; Owens, V.N. Soil carbon dioxide fluxes in stablished switchgrass land managed for biomass production. Soil Biol. Biochem., 2007. 39, 178-186, http://dx.doi.org/10.1016/j.soilbio.2006.07.004.

11. Lynd, L.R.; Cushman, J.H.; Nichols, R.J.; Wyman, C.E. Fuel ethanol from cellulosic biomass. Science, 1991. 251, 1318-1323, http://dx.doi.org/10.1126/science.251.4999.1318.

12. McLaughlin, S.B.; Ugarte, D.G.D.L.; Garten, C.T.; Lynd, L.R.; Sanderson, M.A.; Tolbert,V.R.; Wolf, D.D. High-value renewable energy from prairie grasses. Envi-ron. Sci. Technol., 2002. 36, 2122-2129, http://dx.doi.org/10.1021/es010963d. 
572 13. McLaughlin, S.B.; Kszos, L.A. Development of switchgrass (Panicum virgatum) as a 573 bioenergy feedstock in the United States. Biomass and Bioenergy, 2005. 28(6), pp.515-535.

574 14. Sanderson, M.A.; Reed, R.L.; McLaughlin, S.B.; Wullschleger, S.D.; Conger, B.V.; Parrish, 575 D.J.; Wolf, D.D.; Taliaferro, C.; Hopkins, A.A.; Ocumpaugh, W.R.; Hussey, M.A.; Read, 576 J.C.; Tischler, C.R. Switchgrass as a sustainable bioenergy crop. Bio resource. Technol. 577 1996. 56, 83-93, http://dx.doi.org/10.1016/0960-8524(95)00176-X.

578 15. Munns, R . Genes and salt tolerance: bringing them together. 2005.

579 16. Keshwani, D.R.; Cheng J.J. Switchgrass for bioethanol and other value-added applications: a $580 \quad$ review. Bioresour Technol., 2009. 100:1515-1523.

581 17. Alderson, J.; Sharp W.C. Grass varieties in the United States. CRC Press, Boca Raton, 1995. $582 \quad$ pp 194-199.

583 18. Chen, Z.H.; Zhou, M.X.; Newman I.A.; Mendham, N.J.; Zhang, G.P.; Shabala, S. Potassium 584 and sodium relations in salinized barley tissues as a basis of differential salt tolerance. Funct 585 Plant Biol., 2007. 34:150-162

19. Montemayor, M.B.; Price J.S.; Rochefort, L.; Boudreau, S. Temporal variations and spatial 587 patterns in saline and waterlogged peat fields. Environ Exp Bot, 2008. 62:333-342

20. Moser, L.E.; Vogel, K.P. Switchgrass, big bluestem, and Indian grass. In: Barnes RF, Miller 589 DA, Nelson CJ (eds) Forages Vol. 1: an introduction to grassland agriculture, 5th edn. Iowa $590 \quad$ State University Press, Ames, 1995. pp 409-420.

591 21. Hitchcock, A.S. Manual of the Grasses of the United States. Second edition revised by Agnes 592 Chase. Dover Publications, 1971. Mineola, NY, pp. 697.

593 22. Ashraf, M.; McNeilly, T. Responses of four Brassica species to sodium 594 chloride. Environmental and Experimental Botany, 1990. 30(4), pp.475-487. 
23. He, T.; Cramer, G.R. Growth and mineral nutrition of six rapid-cycling Brassica species in response to seawater salinity. Plant and Soil, 1992. 139(2), pp.285-294.

24. Boem, F.H.; Scheiner, J.D.; Lavado, R.S. Some effects of soil salinity on growth, development and yield of rapeseed (Brassica napus L.).Journal of Agronomy and Crop Science, 1994. 172(3), pp.182-187.

25. Grewal, H.S. Water uptake, water use efficiency, plant growth and ionic balance of wheat, barley, canola and chickpea plants on a sodic vertosol with variable subsoil $\mathrm{NaCl}$ salinity. Agricultural Water Management, 2010. 97(1), pp.148-156.

26. Porcelli, C.A.; Boem, F.H.G.; Lavado, R.S. The K/Na and $\mathrm{Ca} / \mathrm{Na}$ ratios and rapeseed yield, under soil salinity or sodicity. Plant and Soil, 1995. 175(2), pp.251-255.

27. Munns, R.; Tester, M. Mechanisms of salinity tolerance. Annu. Rev. Plant Biol., 2008. 59:651-681New phytol 167:645-663.

28. Burkhardt, A.; Gawde, A.; Cantrell, C.L.; Baxter, H.L.; Joyce, B.L.; Stewart, C.N.; Zheljazkov, V.D. Effects of produced water on soil characteristics, plant biomass, and secondary metabolites. Journal of environmental quality, 2015. 44(6), pp.1938-1947.

29. Mullins, G.L.; Hajek, B.F. Effects of coalbed methane-produced water on sorghumsudangrass growth and soil chemical properties Commun. Soil Sci.Plant Anal., 1998. 29 (1516), 2365-2381.

30. Vance, G.F.; King, L.A.; Ganjegunte, G.K.; Soil and plant responses from land application of saline-sodic waters: implications of management. J. Environ. Qual., 2008. 37, 139-148.

31. Zheljazkov, V.D.; Cantrell, C.L.; Astatkie, T.; Schlegel, V.; Jeliazkova, E.; Lowe, D. The effect of coal-bed methane water on spearmint and peppermint. J. Environ. Qual., 2013. 42, $1815-1821$. 
32. Anderson EK, Voigt TB, Kim S, Lee DK. Determining effects of sodicity and salinity on switchgrass and prairie cordgrass germination and plant growth. Industrial Crops and Products. 2015 Feb 28;64:79-87.

33. Smith, D. Removing and analyzing total nonstructural carbohydrates from plant tissue. Research Reports. 1969. Wisconsin Coll. Agric. Life Sci., 41.

34. American Public Health Association, American Water Works Association, Water Pollution Control Federation, and Water Environment Federation. 2013. Standard Methods for the Examination of Water and Wastewater, Vol. 2.

35. Watson, M.E.; Brown, J.R. pH and Lime Requirement. In: J.R. Brown, (Ed.).Recommended chemical soil test procedures for the north central region. North Central Region Publication No. 221 (Revised).1998. Missouri Agricultural Experiment Station SB 1001.

36. Carson, P.L. Recommended nitrate-nitrogen tests. In: W.C. Dahnke, (Ed.).Recommended Chemical Soil Test Procedures for the North Central Region. North Central Region Publication No. 221 (Revised).1980.

37. Dahnke, W.C.; Whitney, D.A. Measurement of soil salinity. In: W.C. Dahnke(Ed.). Recommended Chemical Soil Test Procedures for the North Central Region. North Central Region Publication No. 221 (Revised) pp. 32-34.1988.

38. Richards, L.A. Diagnosis and improvement of saline and alkaline soils. Washington: United States Salinity Laboratory Staff, 1954. 160 p. Agriculture Handbook, 60.

39. Knudsen, D.; Beegle, D. Recommended phosphorus tests. In: W.D. Dahnke,(Ed.) Recommended Chemical Soil Test Procedures for the North Central Region, North Central Region Publication No. 221. 1988 
40. Brown, J.R.; Warncke, D. Recommended cation tests and measures of cation exchange capacity. In: W.C. Dahnke, (Ed.). Recommended Chemical Soil Test Procedures for the North Central Region. North Central Region Publication No.221 (Revised). North Dakota Agric. Exp. Stn. Bull. 499 (Revised). 1988.

41. Whitney, D.A. Micronutrient soil tests for zinc, iron, manganese and copper. In: w.c. Dahnke, (ed.). Recommended chemical soil test procedures for the north central region. North Central Region Publication No. 221 (Revised). North Dakota Agric. Exp. Stn. Bull. 499 (Revised). 1988.

42. Khan, M.A., Ungar, I.A. The effect of salinity and temperature on germination of polymorphic seeds and growth of Atriplextriangularis Wild. Am J Bot., 1984. 71:481-489

43. Timson, J. New method of recording germination data. Nature, 1965. 207:216-217

44. Kim, J.; Liu, Y.; Zhang, X.; Zhao, B.; Childs, K.L. Analysis of salt-induced physiological and proline changes in 46 switchgrass (Panicum virgatum) lines indicates multiple response modes. Plant Physiology and Biochemistry,2012. 105, pp.203-212.

45. Morris, K.N.; Shearman, R.C. October. NTEP Turfgrass evaluation guidelines. In NTEP turfgrass evaluation workshop, Beltsville, MD, pp. 1-5.1998.

46. Marcum, K.B.; Anderson, S.J.; Engelke, M.C. Salt gland ion secretion: a salinity tolerance mechanism among five zoysiagrass species. Crop Sci., 1998. 38:1414-1414

47. Debez, A.; Ben Hamed, K.; Grignon, C.; Abdelly, C. Salinity effects on germination, growth, and seed production of the halophyte Cakile maritima. Plant Soil, 2004. 262:179-189

48. Farhadian, M.; Vachelard, C.; Duchez, D.; Larroche, C. In situ bioremediation of monoaromatic pollutants in groundwater: a review. Bioresource Technology, 2008. 99(13), pp.5296-5308. 
663

664

665

666

667

668

669

670

671

672

673

674

675

676

677

678

679

680

681

682

683

684

49. Young, L.Y.; Phelps, C.D. Metabolic biomarkers for monitoring in situ anaerobic hydrocarbon degradation. Environmental health perspectives, 2005. pp. 62-67.

50. Beller, H.R.; Ding, W.H.; Reinhard, M. Byproducts of anaerobic alkylbenzene metabolism useful as indicators of in situ bioremediation. Environmental science \& technology, 1995. 29(11), pp.2864-2870.

51. Chakraborty, R.; Coates, J.D. Anaerobic degradation of monoaromatic hydrocarbons. Applied Microbiology and Biotechnology, 2004. 64(4), pp.437-446.

52. Cunningham, J.A.; Rahme, H.; Hopkins, G.D.; Lebron, C.; Reinhard, M. Enhanced in situ bioremediation of BTEX-contaminated groundwater by combined injection of nitrate and sulfate. Environmental science \& technology, 2001. 35(8), pp.1663-1670.

53. Da Silva, M.L.; Ruiz-Aguilar, G.M.; Alvarez, P.J. Enhanced anaerobic biodegradation of BTEX-ethanol mixtures in aquifer columns amended with sulfate, chelated ferric iron or nitrate. Biodegradation, 2005. 16(2), pp.105-114.

54. Kim, S.; Rayburn, A.L.; Voigt, T.; Parrish, A.; Lee, D.K. Salinity effects on germination and plant growth of prairie cordgrass and switchgrass. Bioenergy Research, 2012. 5(1), pp.225235.

55. Marcum, K.B. . Cell membrane thermos ability and whole-plant heat tolerance of Kentucky bluegrass. Crop Sci. 1998. 38:1214-1218

56. Blum, A.; Ebercon, A. Cell membrane stability as a measure of drought and heat tolerance in wheat. Crop Sci. 1981. 21:43-47

57. Liu, X.; Bingru, H. Heat stress injury in relation to membrane lipid peroxidation in creeping bentgrass. Crop Science 40, no. 2, 2000,: 503-510. 

695

696

697

698

699

700

701

702

703

704

705

706

707

695

705

07

58. Bilgili, U.; Carpici, E.B.; AŞIK, B.B.; Celik, N. Root and shoot response of common vetch (vicia sativa 1.), forage pea (pisum sativum 1.) and canola (brassica napus 1.) to salt stress during early se. Turkish Journal of Field Crops, 2011. 16(1), pp.33-38.

59. Francois, L.E., Donovan, T.J., Maas, E.V., Lesch, S.M., 1994. Time of salt stress affects growth and yield components of irrigated wheat. Agron. J. 86, 100-107.

60. Liu, Y.; Wang, Q.; Zhang, Y.; Cui, J.; Chen, G.; Xie, B.; Wu, C.; Liu, H. Synergistic and antagonistic effects of salinity and $\mathrm{pH}$ on germination in switchgrass (Panicum virgatum L.). PloS one, 2014. 9(1), p.e85282.

61. Farhoudi, R. Effect of salt stress on physiological and morphological parameters of rapeseed cultivars. Adv. Environ. Biol, 2011. 5(8), pp.2501-2508.

6

7

8

9

0

1

02

03

04

06




\section{Sustainable Water Management}

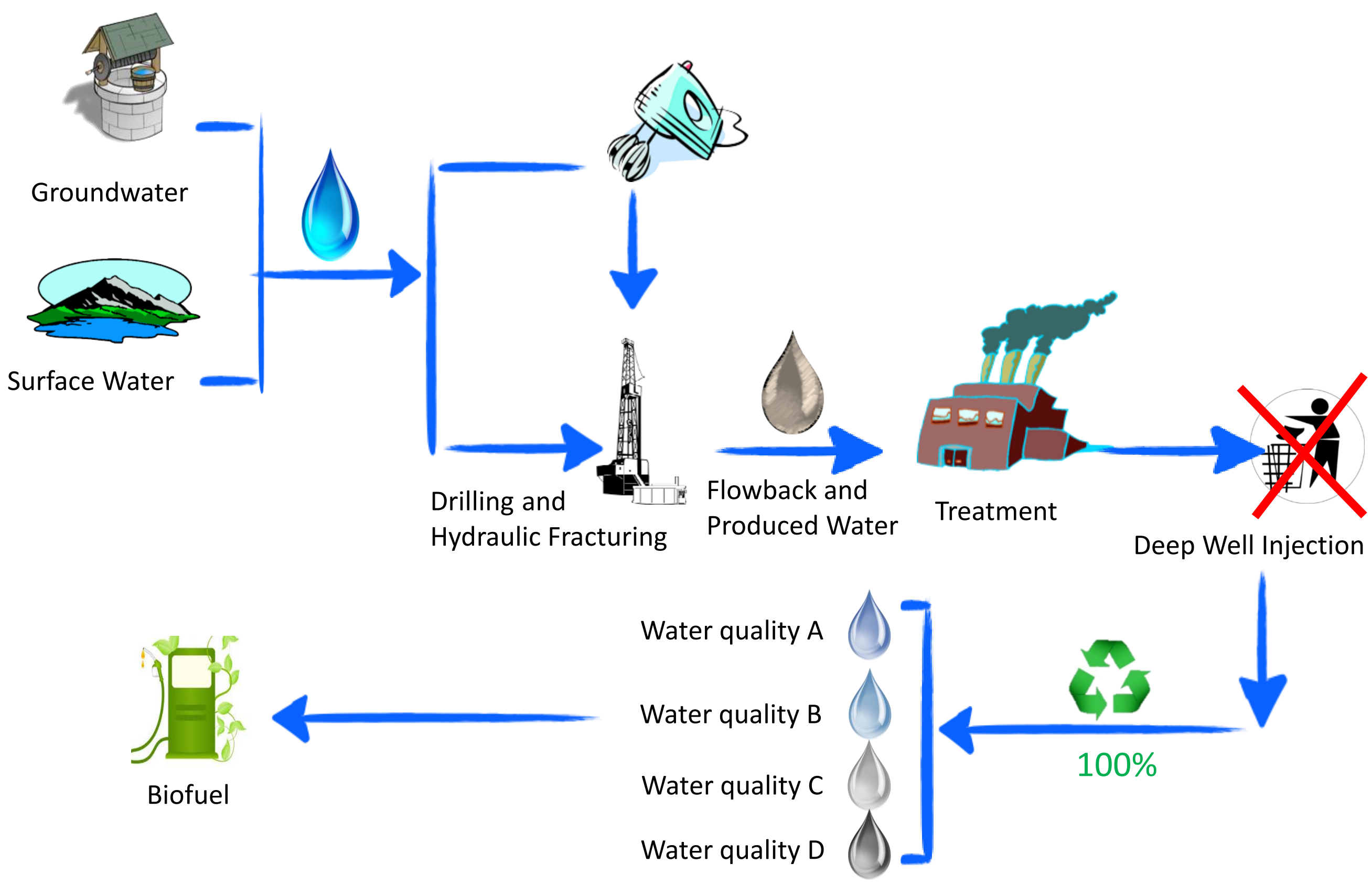


Table 1- Organic characteristics of water samples

\begin{tabular}{|c|c|c|c|c|c|c|c|c|c|c|}
\hline Sample & $\begin{array}{l}\text { TOC } \\
(\mathrm{mg} / \mathrm{l})\end{array}$ & $\pm \mathrm{SE}$ & $\begin{array}{l}\text { Benzene } \\
\text { (ug/L) }\end{array}$ & $\pm \mathrm{SE}$ & $\begin{array}{l}\text { Toluene } \\
\text { (ug/L) }\end{array}$ & $\pm \mathrm{SE}$ & $\begin{array}{l}\text { Ethyl } \\
\text { benzene } \\
\text { (ug/L) }\end{array}$ & $\pm \mathrm{SE}$ & $\begin{array}{l}\text { total } \\
\text { xylenes } \\
(\mathrm{ug} / \mathrm{L})\end{array}$ & $\pm \mathrm{SE}$ \\
\hline $\begin{array}{l}\text { Irrigation } \\
\text { water A }\end{array}$ & 3.3 & 0.0 & 0.0 & 0.0 & 0.0 & 0.0 & 0.0 & 0.0 & 0.0 & 0.0 \\
\hline $\begin{array}{l}\text { Irrigation } \\
\text { water B }\end{array}$ & 1.2 & 0.5 & 1 & 0.6 & 1.2 & 1.2 & 0.0 & 0.0 & 0.0 & 0.0 \\
\hline $\begin{array}{l}\text { Irrigation } \\
\text { water C }\end{array}$ & 38.3 & 19.2 & 5.8 & 2.6 & 7.3 & 3.6 & 0.4 & 0.3 & 2.1 & 1.8 \\
\hline $\begin{array}{l}\text { Irrigation } \\
\text { water D }\end{array}$ & 232.2 & 41.3 & 580 & 0.0 & 200 & 0.0 & 5.8 & 0.0 & 30.0 & 0.0 \\
\hline Irrigation & 1352. & 108.5 & 1632 & 314.2 & 888 & 203.9 & 50.8 & 10.7 & 268.0 & 59.6 \\
\hline
\end{tabular}


water E 4

721

722

723

724

725

726

727

728

729

730

Table 2- Cationic characteristics of water samples

\begin{tabular}{|c|c|c|c|c|c|c|c|c|c|c|c|c|}
\hline Sample & $\begin{array}{l}\mathrm{Na} \\
(\mathrm{mg} / \mathrm{l})\end{array}$ & $\pm \mathrm{SE}$ & $\begin{array}{l}\mathrm{K} \\
(\mathrm{mg} / \mathrm{l})\end{array}$ & $\pm \mathrm{SE}$ & $\begin{array}{l}\mathrm{Ca} \\
(\mathrm{mg} / \mathrm{l})\end{array}$ & $\pm \mathrm{SE}$ & $\begin{array}{l}\mathrm{Mg} \\
(\mathrm{mg} / \mathrm{l})\end{array}$ & $\pm \mathrm{SE}$ & $\begin{array}{l}\text { SAR } \\
(\mathrm{mg} / \mathrm{l})\end{array}$ & $\pm \mathrm{SE}$ & $\begin{array}{l}\mathrm{Sr} \\
(\mathrm{mg} / \mathrm{l})\end{array}$ & $\pm \mathrm{SE}$ \\
\hline $\begin{array}{l}\text { Irrigation } \\
\text { water A }\end{array}$ & 3.6 & 0.0 & 0.8 & 0.0 & 14.4 & 0.0 & 1.8 & 0.0 & 1.8 & 0.0 & $<0.1$ & 0.0 \\
\hline $\begin{array}{l}\text { Irrigation } \\
\text { water B }\end{array}$ & 50.0 & 9.8 & 5.3 & 0.4 & 10.5 & 0.4 & 2.1 & 0.1 & 5.2 & 0.9 & NA & NA \\
\hline $\begin{array}{l}\text { Irrigation } \\
\text { water C }\end{array}$ & 1275.0 & 246.6 & 119.0 & 42.1 & 13.0 & 0.8 & 13.1 & 2.1 & 84.2 & 15.4 & 0.3 & 0.1 \\
\hline $\begin{array}{l}\text { Irrigation } \\
\text { water D }\end{array}$ & 1500.0 & 408.3 & 21.0 & 5.7 & 61.0 & 11.4 & 9.1 & 1.6 & 65.6 & 12.2 & NA & NA \\
\hline $\begin{array}{l}\text { Irrigation } \\
\text { water E }\end{array}$ & 5175.0 & 1379.5 & 100.0 & 4.1 & 207.5 & 8.7 & 27.8 & 1.3 & 127.6 & 34.9 & 37.0 & 0.8 \\
\hline
\end{tabular}


Table 3- Anionic characteristics of water samples

\begin{tabular}{|c|c|c|c|c|c|c|c|c|c|c|c|}
\hline Sample & $\begin{array}{l}\text { TDS } \\
(\mathrm{mg} / \mathrm{l})\end{array}$ & $\begin{array}{c}\text { EC } \\
(\mathrm{ds} / \mathrm{m})\end{array}$ & $\begin{array}{l}\text { B } \\
(\mathrm{mg} / \mathrm{l})\end{array}$ & $\pm \mathrm{SE}$ & $\begin{array}{l}\mathrm{Br} \\
(\mathrm{mg} / \mathrm{l})\end{array}$ & $\pm \mathrm{SE}$ & $\begin{array}{l}\mathrm{Cl} \\
(\mathrm{mg} / \mathrm{l})\end{array}$ & $\pm \mathrm{SE}$ & $\begin{array}{l}\mathrm{SO} 4 \\
(\mathrm{mg} / \mathrm{l})\end{array}$ & $\pm \mathrm{SE}$ & $\begin{array}{l}\mathrm{PO} 4 \\
(\mathrm{mg} / \mathrm{l})\end{array}$ \\
\hline $\begin{array}{l}\text { Irrigation } \\
\text { water A }\end{array}$ & 350 & 0.6 & 0.0 & 0.0 & $<0.1$ & 0.0 & 19.2 & 0.0 & $<0.5$ & 0.0 & $<0.5$ \\
\hline $\begin{array}{l}\text { Irrigation } \\
\text { water B }\end{array}$ & 400 & 0.6 & 0.0 & 0.0 & NA & NA & 90.5 & 15.9 & $\mathrm{NA}$ & NA & 0.0 \\
\hline $\begin{array}{l}\text { Irrigation } \\
\text { water C }\end{array}$ & 3500 & 5.5 & 7.3 & 6.4 & 17.5 & 0.4 & 2375.0 & 433.0 & 42.0 & 11.4 & 0.0 \\
\hline $\begin{array}{l}\text { Irrigation } \\
\text { water D }\end{array}$ & 3500 & 5.5 & 2.6 & 1.5 & NA & $\mathrm{NA}$ & 2950.0 & 530.7 & $\mathrm{NA}$ & NA & 0.0 \\
\hline Irrigation & 21000 & 34.4 & 22.0 & 0.4 & 135.0 & 4.1 & 10975.0 & 1591.9 & 49.0 & 4.9 & 0.0 \\
\hline
\end{tabular}


water $\mathrm{E}$

743

NA: not available, SE: standard deviation

744

745

746

747

748

749

750

751

752

753

754

755

Table 4- Soil characteristics

\begin{tabular}{llllllllll}
\hline & Sand & Clay & Silt & $\mathrm{pH}$ & $\mathrm{EC}$ & $\mathrm{OM}$ & $\mathrm{NO3}$ & $\mathrm{P}$ & $\mathrm{SAR}$ \\
& & & & & $\mathrm{ds} / \mathrm{m}$ & $\%$ & $\mathrm{mg} / \mathrm{l}$ & $\mathrm{mg} / \mathrm{l}$ & \\
& & & & & & & & & \\
& & & & & & & & & \\
\hline Clay loam & $34 \%$ & $28 \%$ & $38 \%$ & 8.2 & 0.5 & 1.0 & 0.86 & 1.3 & 4.2
\end{tabular}

756

757

758

759

760 
761 Table 5- Germination percentage and rate under growth chamber conditions for rapeseed and switchgrass subjected

762 to varying levels of sodicity and salinity from five produced water treatments. Treatment means followed by a

763 different letter are different at $P$ less than or equal to 0.05 .

\begin{tabular}{|c|c|c|c|c|c|}
\hline \multirow{3}{*}{ Species } & \multirow{3}{*}{$\begin{array}{l}\text { Irrigation water } \\
\text { treatment }\end{array}$} & \multirow{2}{*}{\multicolumn{2}{|c|}{ Relative germination }} & \multirow{2}{*}{\multicolumn{2}{|c|}{ Germination rate }} \\
\hline & & & & & \\
\hline & & \multicolumn{2}{|l|}{$\%$} & \multicolumn{2}{|l|}{$\%$} \\
\hline & $\mathrm{A}$ & 97.3 & $\bar{a}$ & 58.3 & $\mathrm{a}$ \\
\hline & $\mathrm{B}$ & 95.0 & $\mathrm{a}$ & 46.0 & $\mathrm{~b}$ \\
\hline \multirow[t]{5}{*}{ Switchgrass } & $\mathrm{C}$ & 9.50 & $\mathrm{a}$ & 43.4 & $\mathrm{~b}$ \\
\hline & $\mathrm{D}$ & 68.0 & $\mathrm{a}$ & 22.8 & $\mathrm{c}$ \\
\hline & $\mathrm{E}$ & 1.3 & $\mathrm{~b}$ & 0.4 & $\mathrm{~d}$ \\
\hline & A & 100.0 & $\mathrm{a}$ & 76.4 & $\mathrm{a}$ \\
\hline & $\mathrm{B}$ & 98.7 & $\mathrm{a}$ & 71.2 & $a, b$ \\
\hline \multirow[t]{3}{*}{ Rapeseed } & $\mathrm{C}$ & 94.7 & $\mathrm{a}$ & 60.0 & $\mathrm{a}, \mathrm{b}$ \\
\hline & $\mathrm{D}$ & 88.0 & $\mathrm{a}$ & 48.2 & $\mathrm{~b}$ \\
\hline & $\mathrm{E}$ & 8.0 & $\mathrm{~b}$ & 0.9 & $\mathrm{c}$ \\
\hline
\end{tabular}

764

765

766

767

768

769

770

771

772 
773 Table 6- Growth characteristics of rapeseed and switchgrass species averaged across all water qualities at the end of 774 the growing season. Letter groups represent significant differences $(p=0.05)$ within each variable.

\begin{tabular}{|c|c|c|c|c|c|c|c|c|}
\hline \multirow[t]{2}{*}{ Species } & \multicolumn{2}{|l|}{ Plant height } & \multicolumn{2}{|c|}{ Above ground biomass } & \multicolumn{2}{|l|}{ Leaf EL } & \multicolumn{2}{|l|}{ EC } \\
\hline & $(\mathrm{cm})$ & & (g) & & (\%) & & $(\mathrm{ds} / \mathrm{m})$ & \\
\hline Rapeseed & 73.8 & a & 28.4 & $a$ & 35.5 & $a$ & 17.0 & $a$ \\
\hline Switchgrass & 37.1 & $b$ & 32.4 & $a$ & 28.5 & $\mathrm{~b}$ & 22.0 & $\mathrm{~b}$ \\
\hline
\end{tabular}

775

776

777

778

779

780

781

782

783

784

785

786

787

788 
Table 7- Growth characteristics of rapeseed and switchgrass species at the end of the growing season. Means followed by different letters are significantly different $(p=0.05)$.

\begin{tabular}{|c|c|c|c|c|c|c|c|}
\hline \multirow{3}{*}{ Species } & & Plant & Above & & & & \\
\hline & Irrigation & height & ground & Underground & Shoot to & Leaf EL & $\mathrm{EC}$ \\
\hline & water & $(\mathrm{cm})$ & biomass (g) & biomass (g) & root ratio & (\%) & (ds/m \\
\hline
\end{tabular}

\begin{tabular}{|c|c|c|c|c|c|c|c|c|c|c|c|c|c|}
\hline & $A$ & 44.3 & $\bar{a}$ & 46.8 & $\bar{a}$ & 14.7 & $a$ & 3.1 & $a$ & 19.2 & $\bar{a}$ & 3.6 & $\bar{a}$ \\
\hline & & 36.3 & $a$ & 42.9 & a. & 11 & $b, c$ & & a & & $a$ & & $a$ \\
\hline & B & & & & $b$ & & & 3.9 & & 23.6 & & 3.3 & \\
\hline Rapeseed & C & 42.3 & a & 29.8 & $a$ & 7.8 & $b$ & 3.8 & $a$ & 32.3 & $b$ & 2.5 & a \\
\hline
\end{tabular}

a,

\begin{tabular}{ccccccccccccccc} 
D & 42.3 & $\mathrm{a}$ & 24.8 & $\mathrm{~b}$ & 6.7 & $\mathrm{c}$ & 3.7 & & 38.7 & $\mathrm{~b}$ & 2 & \\
$\mathrm{E}$ & 19 & $\mathrm{~b}$ & 6.2 & $\mathrm{~b}$ & 1.9 & $\mathrm{~d}$ & 3.3 & $\mathrm{a}$ & 63.6 & $\mathrm{c}$ & 16.1 & $\mathrm{~b}$ \\
\hline A & 89.3 & $\mathrm{a}$ & 46.8 & $\mathrm{a}$ & $*$ & $*$ & $*$ & $*$ & 10.7 & $\mathrm{a}$ & 3.3 & $\mathrm{a}$ \\
$\mathrm{B}$ & 81.7 & $\mathrm{a}$ & 42.6 & $\mathrm{a}$ & $*$ & $*$ & $*$ & $*$ & 15.8 & $\mathrm{~b}$ & 3.3 & $\mathrm{a}$
\end{tabular}

Switch-

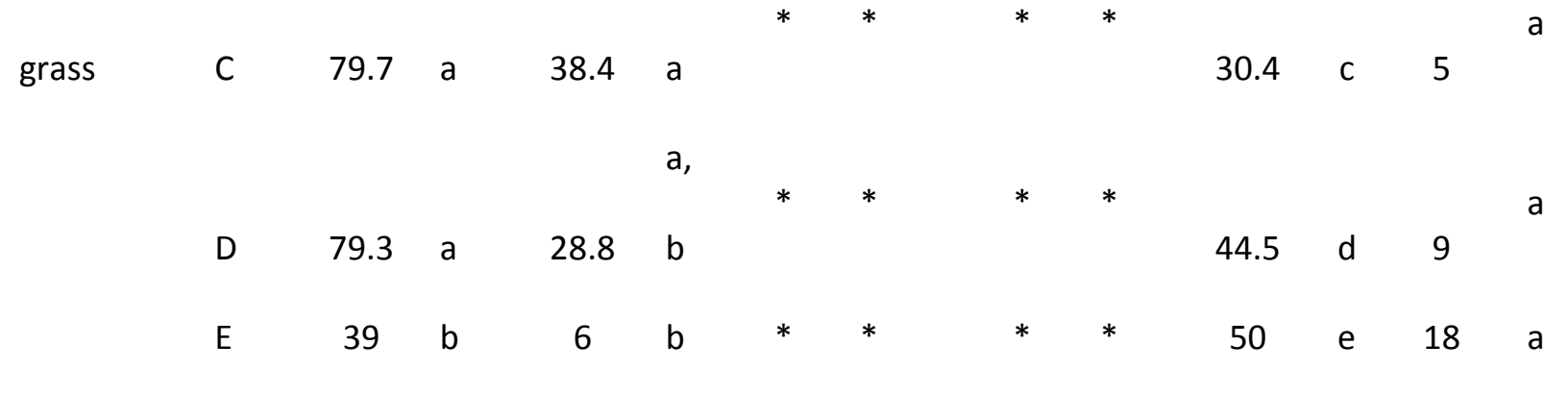



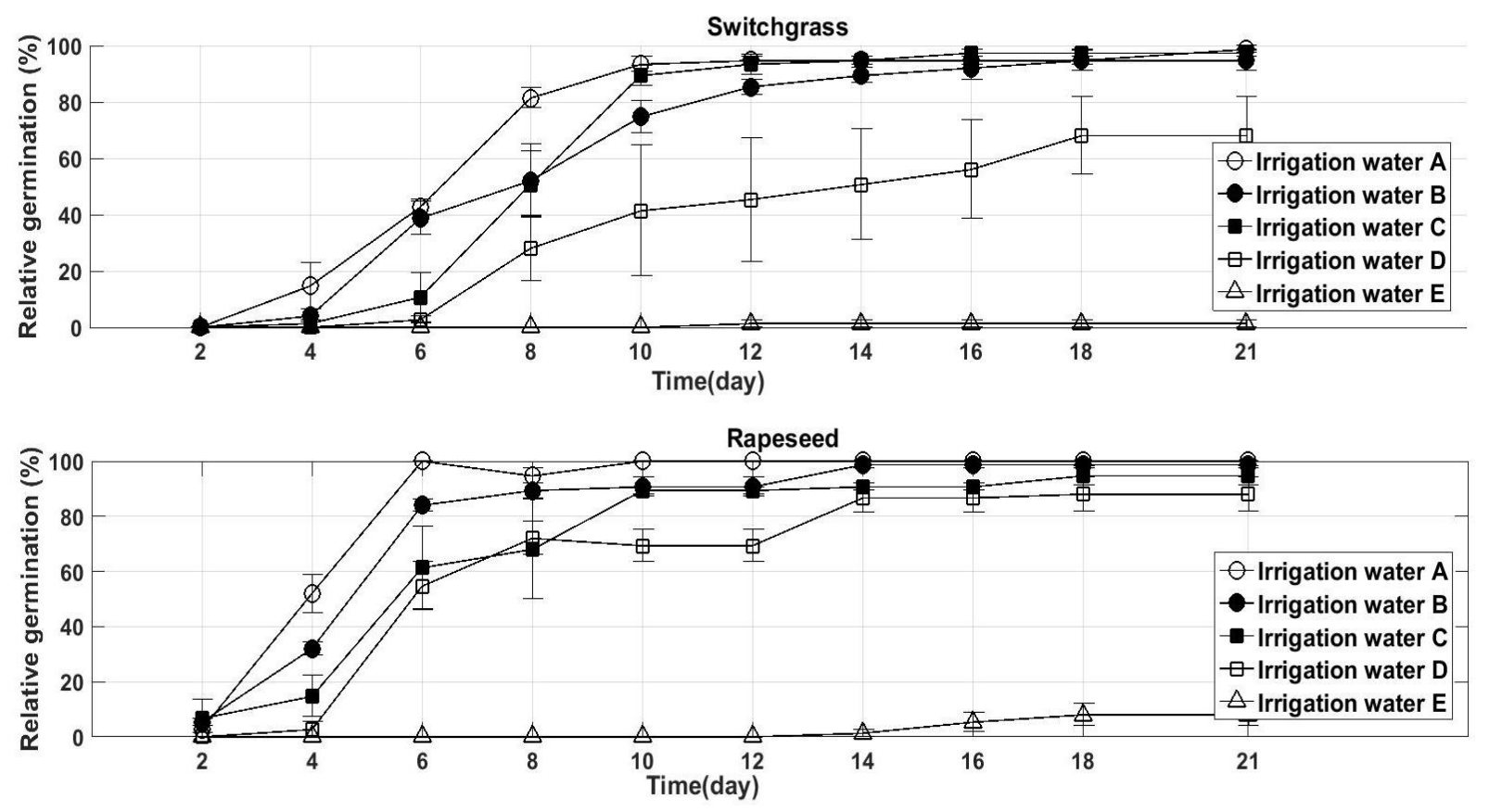


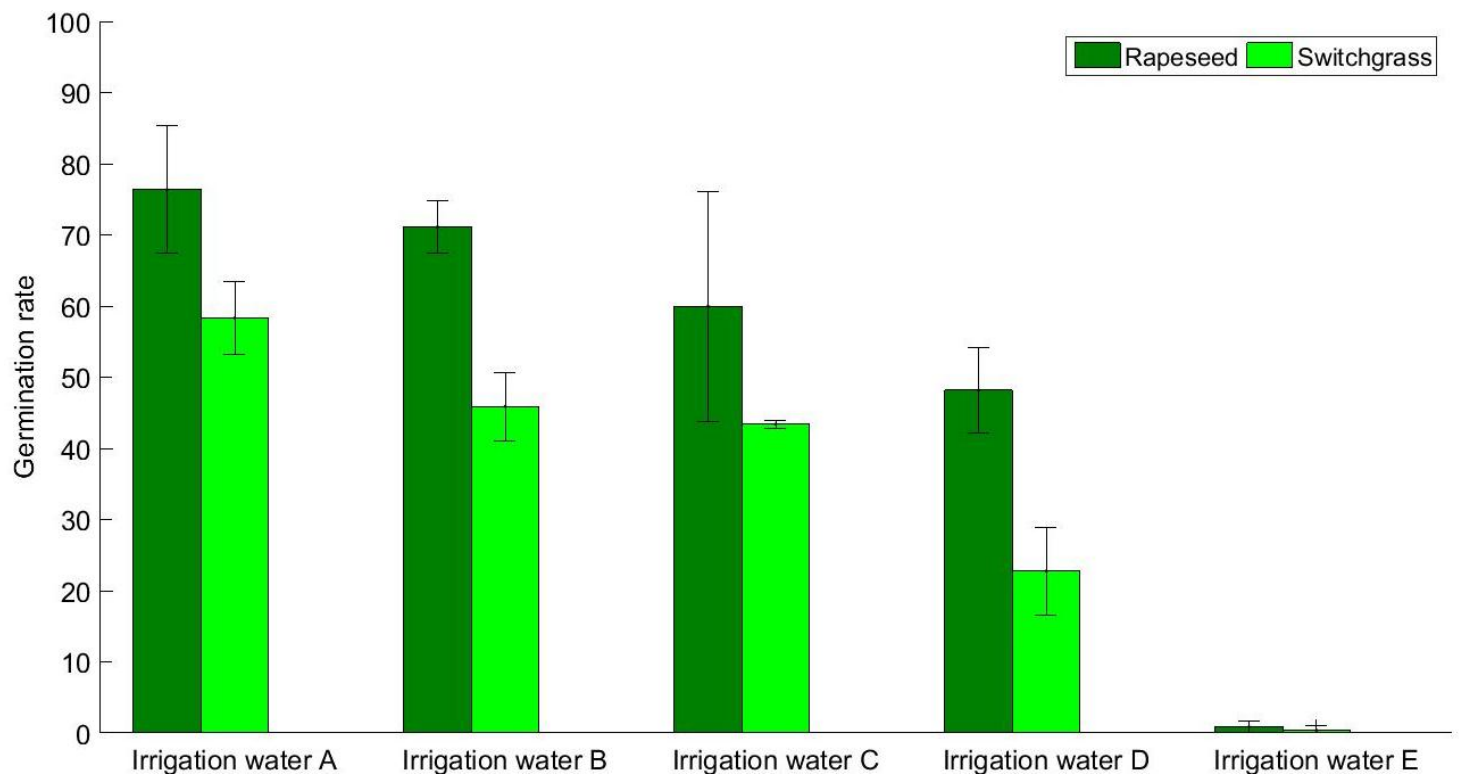

Figure 2- Effect of water quality on germination rate of switchgrass and rapeseed crops 


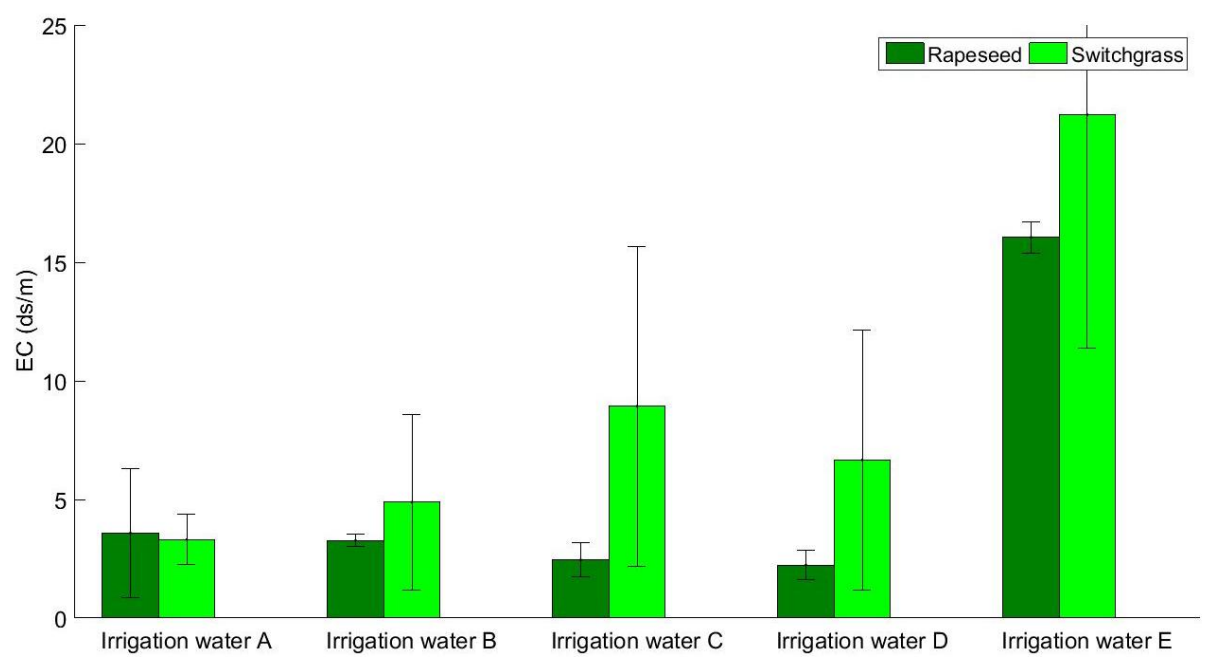

Figure 3-Effect of five water quality types on soil electroconductivity from pots of rapeseed and switchgrass 

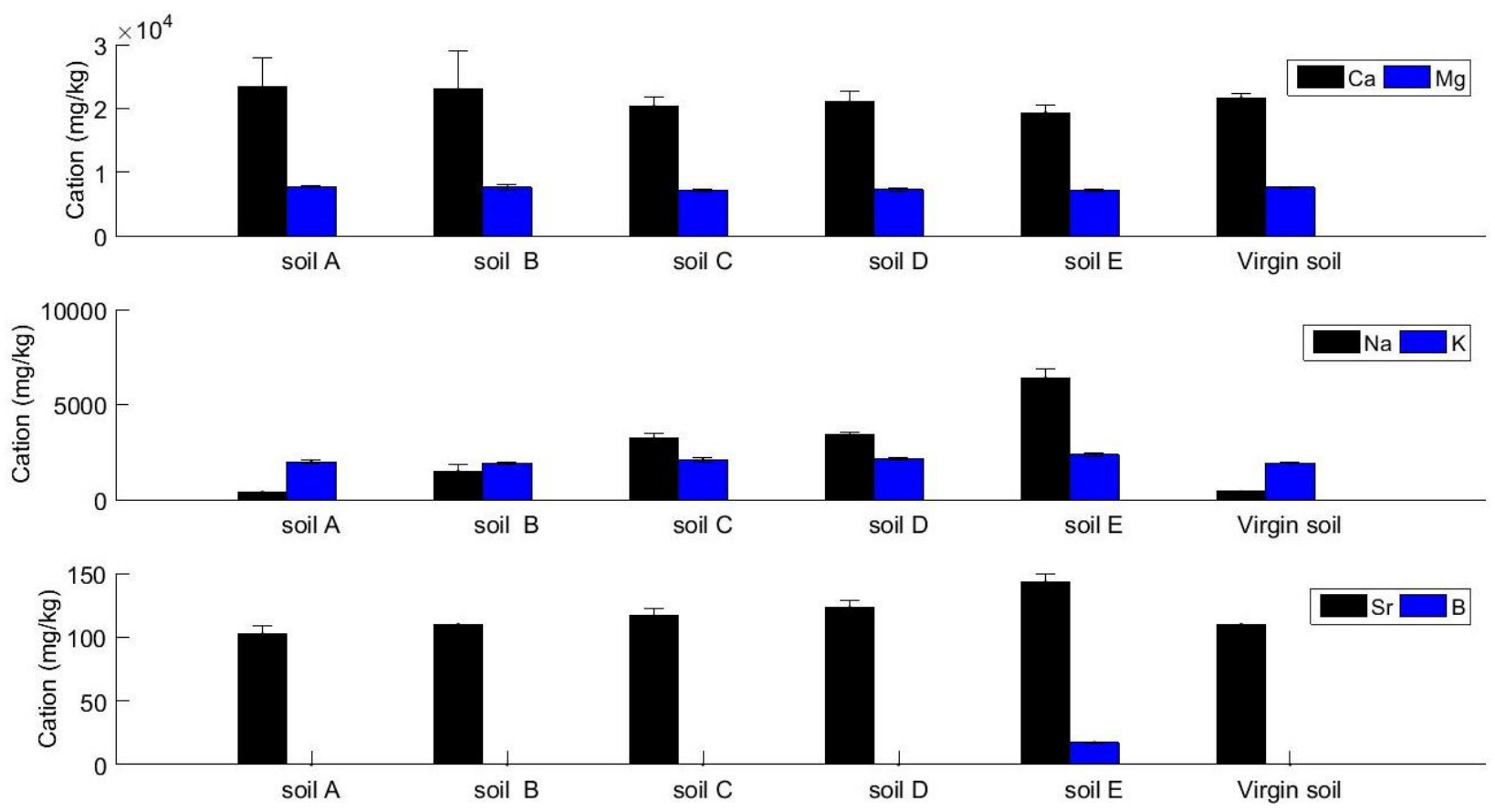

$844 \quad$ Figure 4- Ionic, $\mathrm{Ca}, \mathrm{Mg}, \mathrm{Na}, \mathrm{K}, \mathrm{Sr}$ and $\mathrm{B}$, content of soils from rapeseed pots for five irrigation waters. 

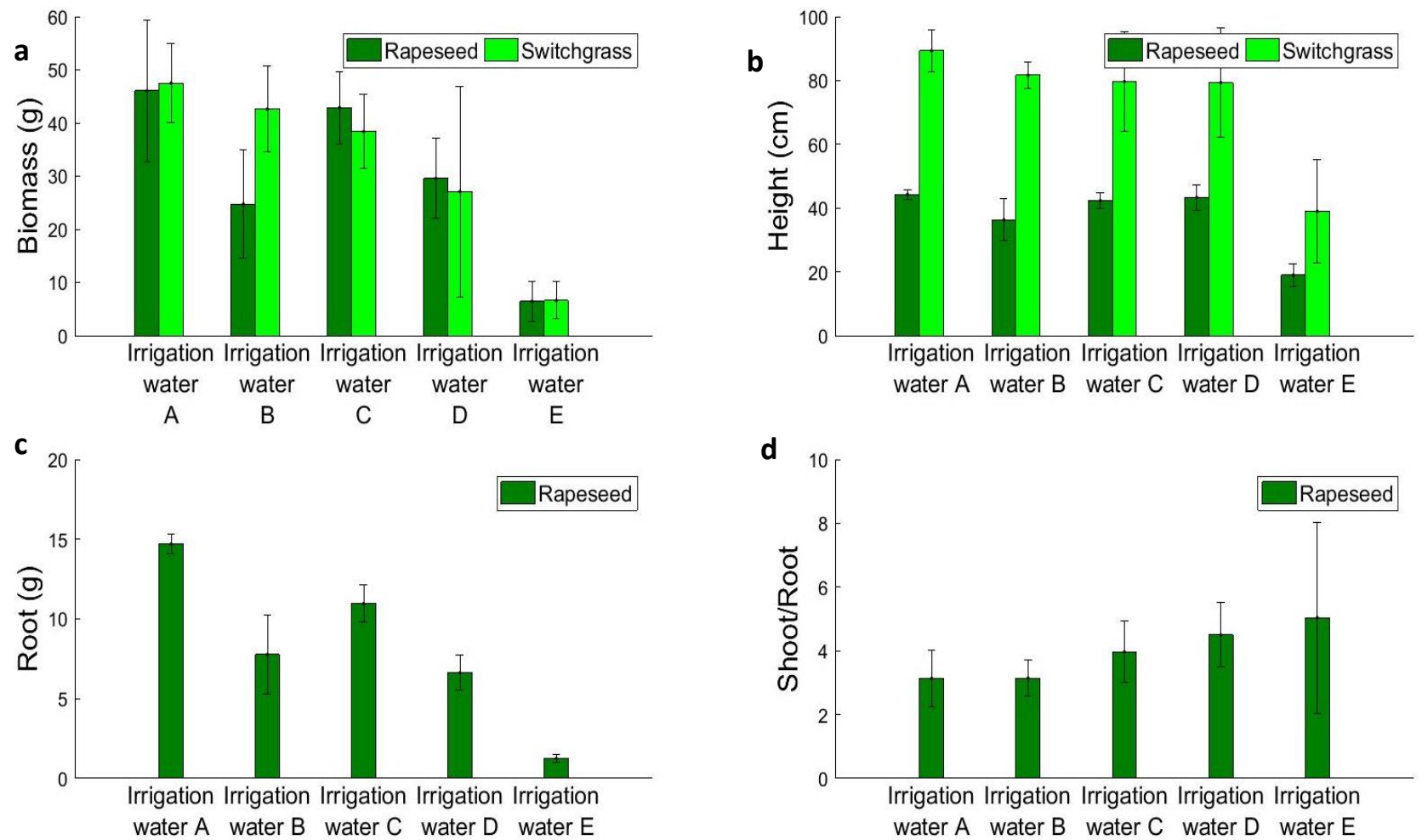

857 Figure 5- Effect of water quality on mean plant biomass yield (a), root weight (b) and height (c) of rapeseed and switchgrass in a greenhouse experiment. Error bars are \pm SEM. 

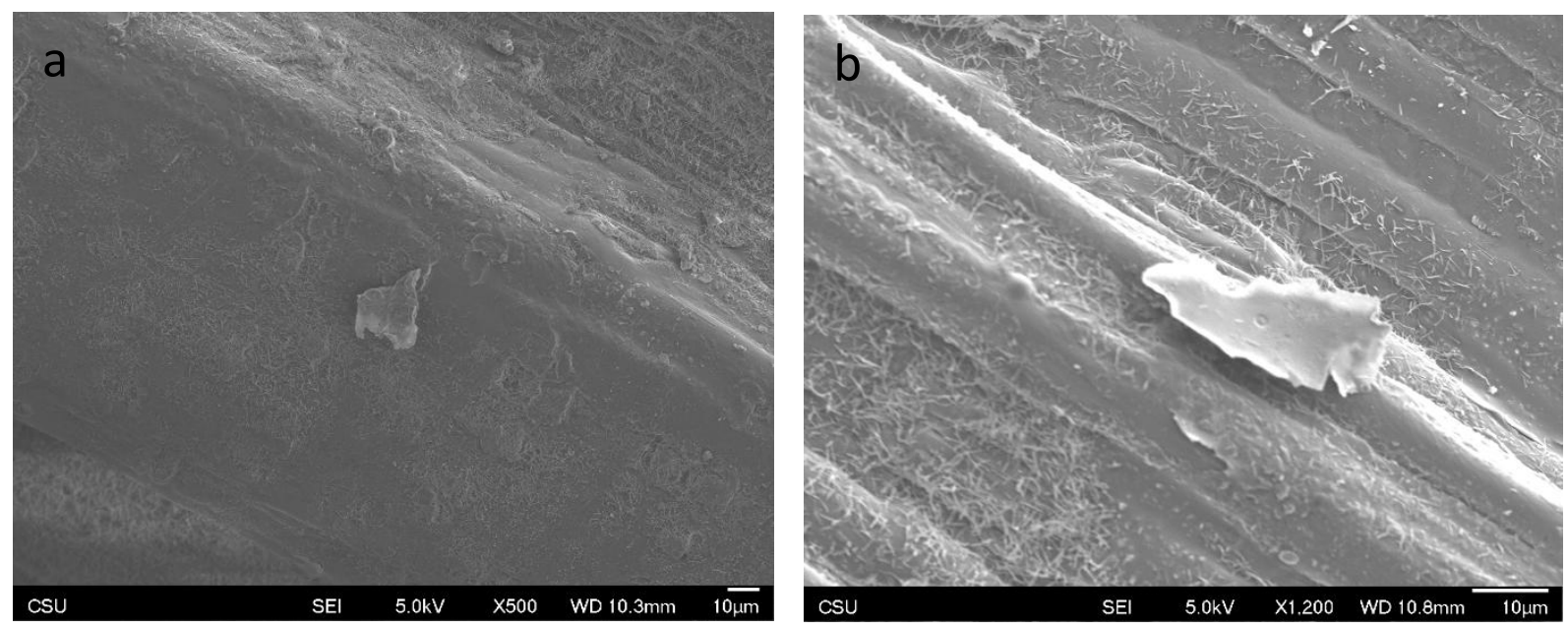

866 Figure 6. Adaxial leaf surface view by scanning electron microscopy of (a) switchgrass and (b) rapeseed treated with

867 irrigation water E salt crystal.

868

869

870

871

872

873

874

875

876

877

878

879 


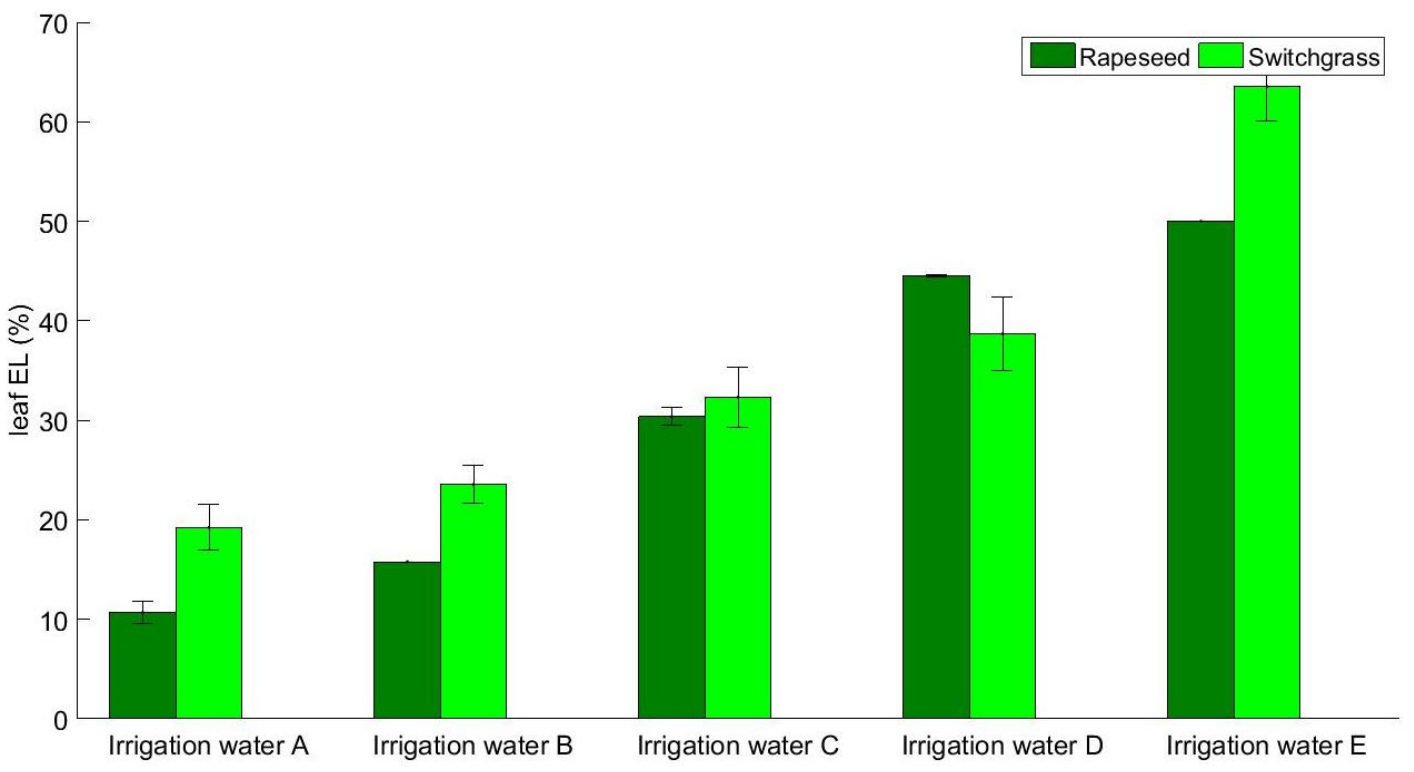



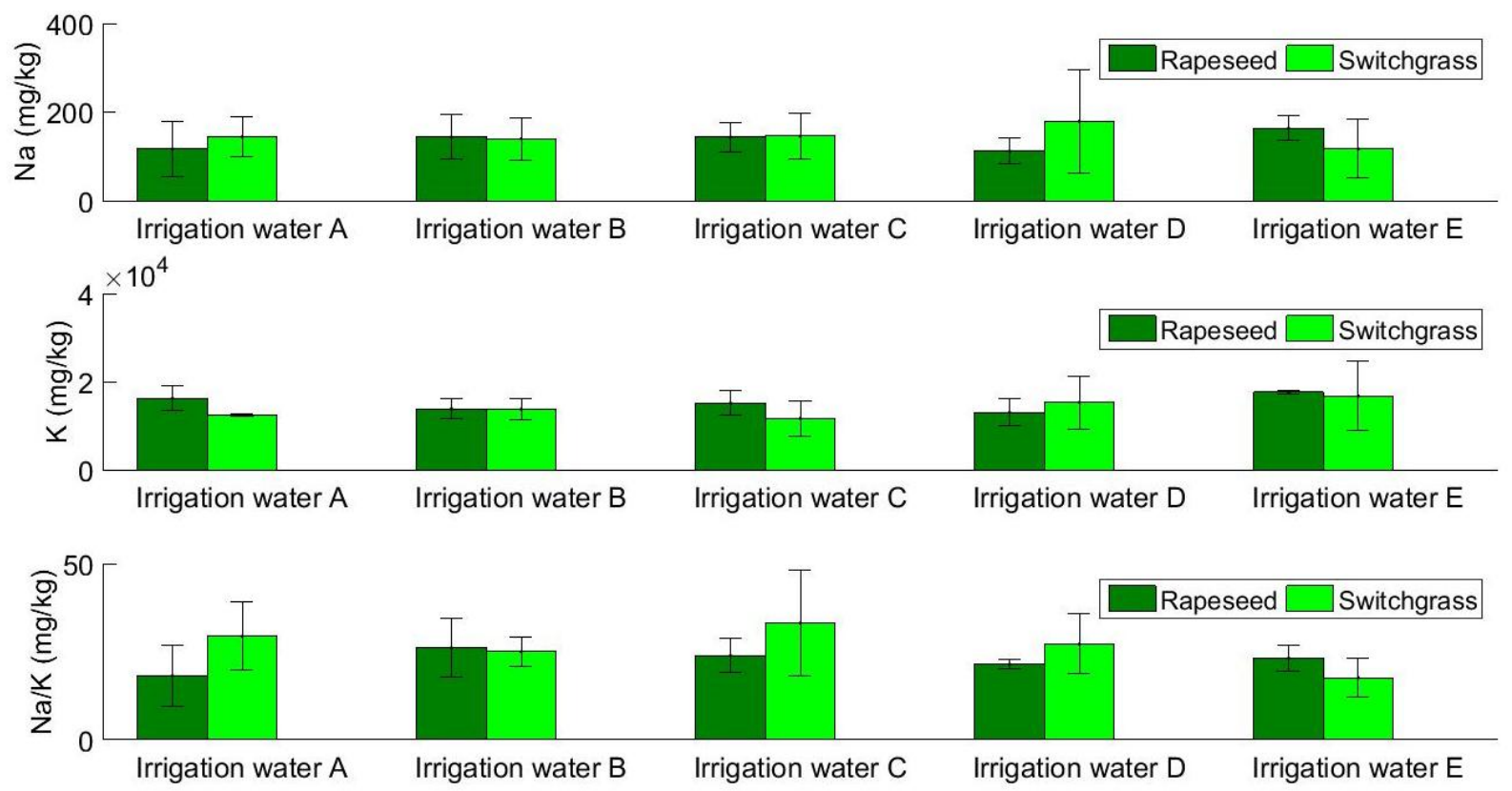

892 Figure 8- Effects of different irrigation water on $\mathrm{Na}, \mathrm{K}$ and selectivity of $\mathrm{K}$ and $\mathrm{Na}$ for rapeseed and switchgrass 893 crops 

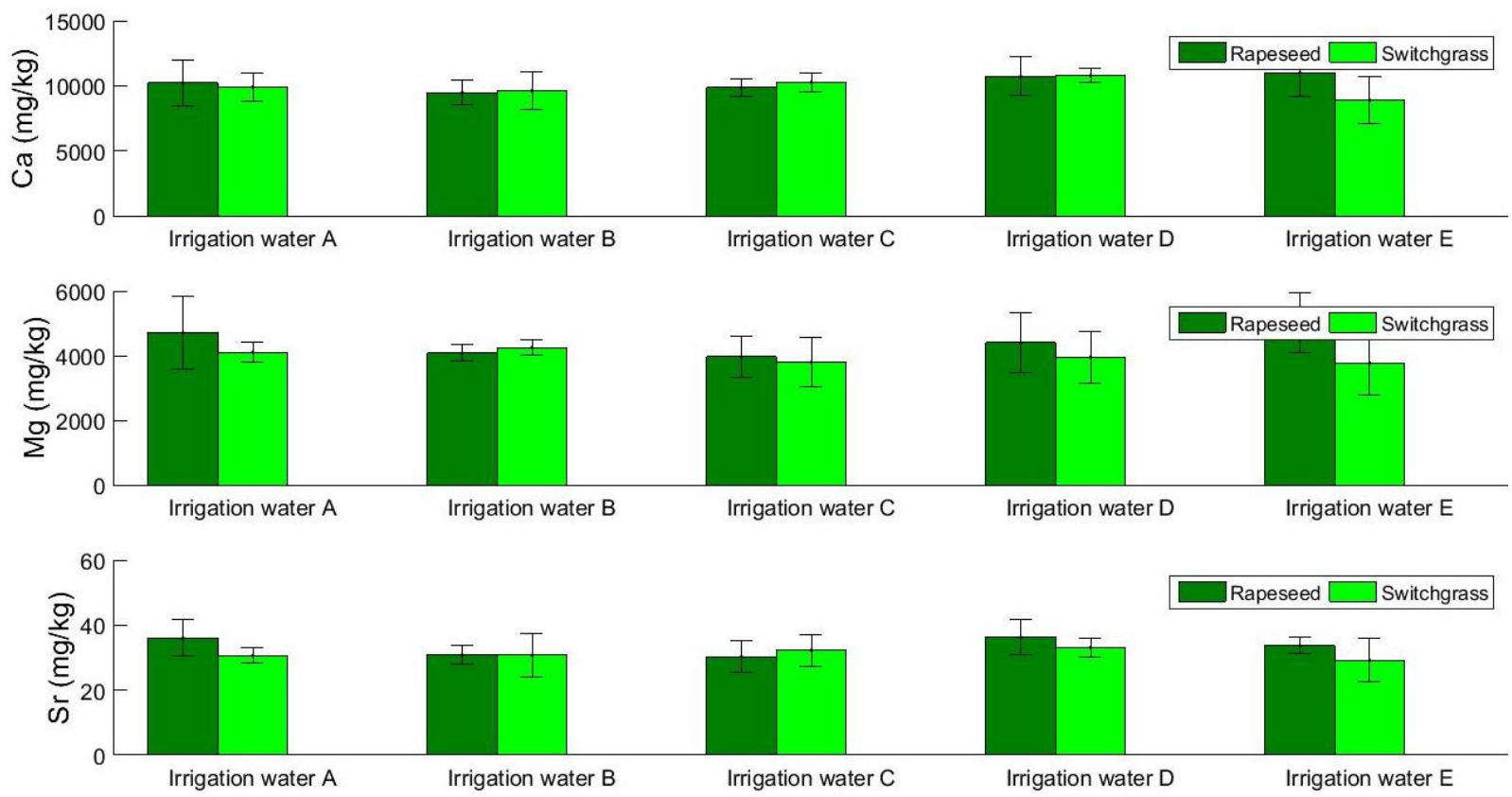

908 Figure 9- Effects of different irrigation water on $\mathrm{Ca}, \mathrm{Mg}$ and $\mathrm{Sr}$ for rapeseed and switchgrass crops 